\title{
Blue to True-Blue Phosphorescent IrIII Complexes Bearing a Nonconjugated Ancillary Phosphine Chelate: Strategic Synthesis, Photophysics, and Device Integration
}

\author{
Yuan-Chieh Chiu, ${ }^{\dagger}$ Yun Chi, ${ }^{*}{ }^{\dagger}$ Jui-Yi Hung, ${ }^{\dagger}$ Yi-Ming Cheng, ${ }^{\ddagger}$ Ya-Chien Yu, ${ }^{\mp}$ \\ Ming-Wen Chung, ${ }^{\ddagger}$ Gene-Hsiang Lee, ${ }^{\neq}$Pi-Tai Chou, ${ }^{*}{ }^{\neq}$Chung-Chia Chen, ${ }^{\S}$ \\ Chung-Chih $\mathrm{Wu},{ }^{*}, \S$ and Hsi-Ying Hsieh"
}

Department of Chemistry, National Tsing Hua University, Hsinchu 300, Taiwan, Departments of Chemistry and of Electrical Engineering, National Taiwan University, Taipei 106, Taiwan, and Department of Food Nutrition, Chung Hwa College of Medical Technology, Tainan 717, Taiwan

\begin{abstract}
We report the design and synthesis of I $^{\text {III }}$ complexes functionalized with substituted pyridyl cyclometalate or azolate chromophores, plus one newly designed nonconjugated phosphine chelate, which not only greatly restricts its participation in the lowest-lying electronic transition but also enhances the coordination strength. These two key factors lead to fine-tuning of the phosphorescence chromaticity toward authentic blue and simultaneously suppress, in part, the nonradiative deactivation. This conceptual design presents a novel strategy in achieving heretofore uncommon, high-efficiency blue and true-blue phosphorescence. The fabrication of the organic light-emitting devices (OLEDs) employing phosphorescent dopants $\left[\operatorname{Ir}(\mathrm{dfpbpy})_{2}\left(\mathrm{P}^{\wedge} \mathrm{N}\right)\right](\mathbf{1} \mathbf{b})$ and $\left[\operatorname{Ir}(\mathrm{fppz})_{2}\left(\mathrm{P}^{\wedge} \mathrm{N}\right)\right](3)$ was successfully made, for which the abbreviations (dfpbpy) $\mathrm{H}$, (fppz)H, and $\left(\mathrm{P}^{\wedge} \mathrm{N}\right) \mathrm{H}$ represent 2-(4,6-difluorophenyl)4-tert-butylpyridine, 3-(trifluoromethyl)-5-(2-pyridyl)pyrazole, and 5-(diphenylphosphinomethyl)-3-(trifluoromethyl)pyrazole, respectively. Of particular interest is the 3-doped OLEDs, which exhibit remarkable maximum efficiencies of $6.9 \%, 8.1 \mathrm{~cd} \mathrm{~A}^{-1}$, and $4.9 \mathrm{~lm}$ $\mathrm{W}^{-1}$, together with a true-blue chromaticity $\mathrm{CIE}_{x, y}=0.163$, with 0.145 recorded at $100 \mathrm{~cd} \mathrm{~m}^{-2}$
\end{abstract}

KEYWORDS: OLEDs • Ir IIII complexes • nonconjugated phosphine chelate • true-blue phosphorescence

\section{INTRODUCTION}

hird-row transition-metal complexes are well-known
for their ability to achieve high-efficiency room tem-
perature phosphorescence (1). As a result, the readily available, $\mathrm{Ru}^{\mathrm{II}} \sim$ (2), Os ${ }^{\mathrm{II}} \sim$ (3), $\mathrm{Ir}^{\mathrm{III}} \sim$ (4) and $\mathrm{Pt}^{\mathrm{II}}$ - based (5) emitting materials have made significant advances in the research of organic light-emitting devices (OLEDs), which are particularly suited to flat-panel display and lighting applications (6). In theory, phosphorescent OLEDs are expected to show higher luminescence and higher efficiency compared with their fluorescent counterparts. This is due to the possibility of achieving $100 \%$ internal quantum efficiency for electroluminescence (EL) (7), a result of effective harvesting for both singlet and triplet excitons.

However, tuning of phosphorescence over the entire visible spectrum still remains a great challenge. On the one

\footnotetext{
*E-mail: ychi@mx.nthu.edu.tw (Y.C.), chop@ntu.edu.tw (P.-T.C.), chungwu@cc.ee.ntu.edu.tw (C.-C.W.).

Received for review October 14, 2008 and accepted January 02, 2009

† National Tsing Hua University.

* Department of Chemistry, National Taiwan University.

$\S$ Department of Electrical Engineering, National Taiwan University

"Chung Hwa College of Medical Technology.

DOI: $10.1021 / a m 800122$ n

( 2009 American Chemical Society
}

hand, many red- and green-emitting phosphors have been reported in the literature. These, incorporating various ingenious structural modifications that allowed the fabrication of OLEDs employing vacuum deposition, solution processes in either the presence or absence of external host materials, have led to very successful device performance (8). On the other hand, tuning phosphorescence to the trueblue region with an ideal $\mathrm{CIE}_{x, y}$ coordinate of $(0.14,0.09)$ is still less successful. Most studied prototypes toward blue are the class of Ir III complexes possessing at least one cyclometalated 4,6-difluorophenylpyridine, (dfppy)H, ligand, known as FIrpic, FIr6, FIrtaz, and many others (9). Blue OLEDs have been fabricated with these phosphors; however, the majority showed inferior color chromaticity, with the sum of $\mathrm{CIE}_{x}+$ $\mathrm{CIE}_{y}$ being much greater than 0.3 or with a single $\mathrm{CIE}_{y}$ coordinate higher than 0.25 (10).

We decided to tackle this challenge by first synthesizing $\mathrm{Os}^{\mathrm{II}}$ complexes known as $\left[\mathrm{Os}(\mathrm{fppz})_{2}(\mathrm{CO})_{2}\right]$, where (fppz)H $=3$-(trifluoromethyl)-5-(2-pyridyl)pyrazole (11), and $\left[\mathrm{Os}(\mathrm{CO})_{3}(\mathrm{tfa})(\mathrm{fppz})\right]$, where $\mathrm{ffa}=$ trifluoroacetate (12). The photophysical data showed correct color chromaticity; unfortunately, the terminally coordinated carbonyl ligands made it electrochemically unstable and hence unsuitable as the true-blue dopant for OLEDs. Subsequently, we have synthesized homoleptic $\left[\operatorname{Ir}(\mathrm{fppz})_{3}\right](13)$ as well as a hetero- 

difluorophenyl- $N$-pyrazole as ancillary nonchromophoric chelates (14). To our surprise, the homoleptic $\left[\operatorname{Ir}(\mathrm{fppz})_{3}\right]$ demonstrated remarkable dual phosphorescence, i.e., showing the coexistence of blue and green emission bands, attributed to the intraligand charge-transfer (ILCT) and ligand-to-ligand charge-transfer (LLCT) transitions, respectively. The fast decay of the blue phosphorescence at room temperature and unexpected rise of a green emission, resulting in a bathochromic shift and a reduction of the emission efficiency (14). In the case of the heteroleptic fppz complex and analogues, while the LLCT is suppressed, room temperature true-blue phosphorescence was clearly noted, depending on the intrinsic characteristics of the ancillary ligands (15); for example, employing the nonconjugated chelating ligands with stronger ligand field strength could induce the light output from the aforementioned fppz chelate with little loss of its emission efficiency (16).

In this study, we reported the preparation of heteroleptic Ir ${ }^{\text {III }}$ complexes by the incorporation of a distinctive $\left(\mathrm{P}^{\wedge} \mathrm{N}\right) \mathrm{H}$ chelate, namely, 5-(diphenylphosphinomethyl)-3-(trifluoromethyl)pyrazole, to serve as the ancillary, nonchromophoric ligand and electronic blocker, together with the employment of well-known dfppy, dfpbpy, or fppz ligands acting as tunable chromophores. This $\mathrm{P}^{\wedge} \mathrm{N}$ chelate represents another new class of "nonconjugated" chelates (15). The $\pi$-accepting character of the $\mathrm{PPh}_{2}$ group is expected to increase the associated metal-to-ligand charge-transfer (MLCT) energy level and to destabilize the ligand field dd excited states at the same time, while its saturated nature would also confine the electronic transition dipole around the dfppy, dfpbpy, or fppz chromophores. As anticipated, blue to trueblue phosphorescences can be achieved through a simple switch of the chromophoric ligands based on a facile synthetic approach elaborated as follows.

\section{EXPERIMENTAL SECTION}

General Information and Materials. All reactions were performed under a nitrogen atmosphere using anhydrous solvents or solvents treated with an appropriate drying reagent. Mass spectra were obtained on a JEOL SX-102A instrument operating in electron impact (EI) or fast atom bombardment (FAB) mode. ${ }^{1} \mathrm{H}$ and ${ }^{19} \mathrm{~F}$ NMR spectra were recorded on a Varian Mercury-400 or INOVA-500 instrument. Elemental analyses were conducted at the NSC Regional Instrumentation Center at National Chiao Tung University.

I. Synthesis of a $\left(\mathrm{P}^{\wedge} \mathrm{N}\right) \mathrm{H}$ Chelate. Synthesis of 4-(2-Tetrahydropyranyloxy)-2-butanone (L1). Pyridine $(0.09 \mathrm{~mL}, 0.01$ $\mathrm{mol}$ ) and $p$-toluenesulfonic acid $(211 \mathrm{mg}, 0.01 \mathrm{~mol})$ were added in hydroxyacetone $(8 \mathrm{~mL}, 0.11 \mathrm{~mol})$, and the mixture was stirred at room temperature for $15 \mathrm{~min}$. To this mixture was added 3,4-dihydro- $2 \mathrm{H}$-pyran $(20.5 \mathrm{~mL}, 0.22 \mathrm{~mol})$ at $0{ }^{\circ} \mathrm{C}$, and then the mixture was stirred at room temperature for another $2.5 \mathrm{~h}$. After that, the excess 3,4-dihydro-2H-pyran was removed under vacuum, giving a pale-yellow liquid that could be purified by flash column chromatography using ethyl acetate and hexane $(1: 4)$ as the eluent. Distillation of the crude product at 55 ${ }^{\circ} \mathrm{C} / 250$ mTorr gave 4-(2-tetrahydropyranyloxy)-2-butanone (L1) as a colorless liquid with a yield of $98 \%(17.1 \mathrm{~g}, 108 \mathrm{mmol})$.

Spectral Data of L1. ${ }^{1} \mathrm{H}$ NMR $\left(400 \mathrm{MHz}, \mathrm{CDCl}_{3}, 294 \mathrm{~K}\right): \delta$ $4.63-4.59(\mathrm{~m}, 1 \mathrm{H}), 4.23(\mathrm{~d}, J=15.6 \mathrm{~Hz}, 1 \mathrm{H}), 4.09(\mathrm{~d}, J=15.6$

$\mathrm{Hz}, 1 \mathrm{H}), 3.83-3.79(\mathrm{~m}, 1 \mathrm{H}), 3.51-3.48(\mathrm{~m}, 1 \mathrm{H}), 2.16(\mathrm{~s}, 3 \mathrm{H})$, $1.85-1.52(\mathrm{~m}, 6 \mathrm{H})$.

Synthesis of 5-[(2-Tetrahydropyranyloxy)methyl]-3-(trifluoromethyl)-1H-pyrazole (L3). NaOEt (4.8 g, 0.07 mol) was dispersed in $80 \mathrm{~mL}$ of dry tetrahydrofuran (THF). To this solution was added L1 (8 g, $50.6 \mathrm{mmol}$ ) slowly at $0{ }^{\circ} \mathrm{C}$. The mixture was stirred for $2 \mathrm{~h}$ followed by the addition of ethyl trifluoroacetate $(6.62 \mathrm{~mL}, 55.6 \mathrm{mmol})$ at $0^{\circ} \mathrm{C}$. The reaction was then heated to $50{ }^{\circ} \mathrm{C}$ for $4 \mathrm{~h}$. Removal of the solvent gave a brown oily residue, which was dispersed in deionized water (50

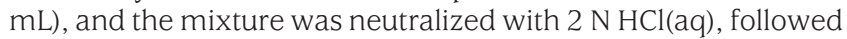
by extraction with ethyl acetate $(30 \mathrm{~mL} \times 3)$. The combined organic layer was dried over anhydrous $\mathrm{Na}_{2} \mathrm{SO}_{4}$. After filtration with $\mathrm{Na}_{2} \mathrm{SO}_{4}$, evaporation of the solvent afforded diketone $\mathbf{L} 2$ as a brown oil that was used without further purification. Next, L2 was dissolved in $50 \mathrm{~mL}$ of EtOH and treated with hydrazine monohydrate $(24.0 \mathrm{~mL}, 0.5 \mathrm{~mol})$. The mixture was refluxed for $24 \mathrm{~h}$. After cooling to room temperature, evaporation of the solvent at reduced pressure gave brown residues, which were then dissolved in ethyl acetate. The organic layer was washed with water $(20 \mathrm{~mL} \times 3)$, dried over $\mathrm{Na}_{2} \mathrm{SO}_{4}$, and then filtered. Removal of ethyl acetate at reduced pressure gave a pale-yellow solid. The final purification was conducted by recrystallization in a mixed solution of ether and hexane at room temperature, giving the desired $\mathrm{L} 3$ in $45 \%$ yield ( $5.7 \mathrm{~g}, 22.8 \mathrm{mmol}$ ).

Spectral Data of L3. ${ }^{1} \mathrm{H}$ NMR (400 MHz, acetone- $\left.d_{6}, 294 \mathrm{~K}\right)$ : $\delta 11.14(\mathrm{br}, 1 \mathrm{H}, \mathrm{NH}), 6.43(\mathrm{~s}, 1 \mathrm{H}), 4.75(\mathrm{~d}, J=13.6 \mathrm{~Hz}, 1 \mathrm{H})$, $4.70(\mathrm{~m}, J=13.6 \mathrm{~Hz}, 1 \mathrm{H}), 4.69-4.66(\mathrm{~m}, 1 \mathrm{H}), 3.91-3.87(\mathrm{~m}$, $1 \mathrm{H}), 3.57-3.53(\mathrm{~m}, 1 \mathrm{H}), 1.84-1.75(\mathrm{~m}, 2 \mathrm{H}), 1.60-1.52(\mathrm{~m}$, 4H).

Synthesis of [3-(Trifluoromethyl)-1H-pyrazol-5-yl]methanol (L4). Compound L3 (2.0 g, $8.0 \mathrm{mmol}$ ) was dissolved in $\mathrm{EtOH}$ $(20 \mathrm{~mL})$. The solution was acidified to $\mathrm{pH}=2$ by the dropwise addition of $2 \mathrm{~N} \mathrm{HCl}(\mathrm{aq})$. The mixture was stirred at room temperature for $12 \mathrm{~h}$, followed by the removal of $\mathrm{EtOH}$ and the addition of deionized water $(20 \mathrm{~mL})$. This aqueous mixture was neutralized by $\mathrm{NaHCO}_{3}$, extracted by ethyl acetate $(20 \mathrm{~mL} \times$ 3 ), and dried over anhydrous $\mathrm{Na}_{2} \mathrm{SO}_{4}$. Removal of the organic solvent gave a pale-yellow solid, which was further purified by recrystallization in a mixture of ether and hexane at room temperature, giving L4 as a white powder in $88 \%$ yield $(1.2 \mathrm{~g}$, $7.0 \mathrm{mmol}$ )

Spectral Data of L4. ${ }^{1} \mathrm{H}$ NMR (400 MHz, acetone- $\left.d_{6}, 294 \mathrm{~K}\right)$ : $\delta 12.66$ (br, $1 \mathrm{H}, \mathrm{NH}), 6.53(\mathrm{~s}, 1 \mathrm{H}, \mathrm{CH}), 4.74(\mathrm{~d}, J=6.8 \mathrm{~Hz}, 2 \mathrm{H}$, $\left.\mathrm{CH}_{2}\right), 4.60(\mathrm{t}, J=6.8 \mathrm{~Hz}, 1 \mathrm{H}, \mathrm{OH})$.

Synthesis of 5-(Bromomethyl)-3-(trifluoromethyl)-1Hpyrazole (L5). A 50 mL flask was charged with L4 (498 mg, 3.0 $\mathrm{mmol}$ ) and $10 \mathrm{~mL}$ of dry diethyl ether. The solution was cooled to $0{ }^{\circ} \mathrm{C}$, and then $\mathrm{PBr}_{3}(1.60 \mathrm{~g}, 600 \mu \mathrm{L}, 6.0 \mathrm{mmol})$ was added slowly. After stirring at room temperature for $48 \mathrm{~h}$, the reaction mixture was poured into $10 \mathrm{~mL}$ of cold water and the excess $\mathrm{PBr}_{3}$ was quenched by the addition of a saturated $\mathrm{NaHCO}_{3}$ solution. The aqueous layer was extracted by diethyl ether (20 $\mathrm{mL} \times 3)$ and then $\mathrm{CH}_{2} \mathrm{Cl}_{2}(20 \mathrm{~mL} \times 3)$ sequentially. The combined organic layer was dried over anhydrous $\mathrm{Na}_{2} \mathrm{SO}_{4}$. Evaporation of the solvent gave L5 as a colorless oil $(513 \mathrm{mg}$, $2.25 \mathrm{mmol}, 75 \%$ ), which was used without further purification.

Spectral Data of L5. MS (EI, $\left.{ }^{81} \mathrm{Br}\right): \mathrm{m} / \mathrm{z} 231\left(\mathrm{M}^{+}\right) .{ }^{1} \mathrm{H}$ NMR $\left(400 \mathrm{MHz}\right.$, acetone- $\left.d_{6}, 294 \mathrm{~K}\right): \delta 13.01(\mathrm{br}, 1 \mathrm{H}, \mathrm{NH}), 6.77$ (s, $1 \mathrm{H}, \mathrm{CH}), 4.75\left(\mathrm{~s}, 2 \mathrm{H}, \mathrm{CH}_{2}\right)$

Synthesis of $\left(P^{\wedge} \boldsymbol{N}\right) \boldsymbol{H}$. A $25 \mathrm{~mL}$ Schlenk flask was charged with diphenylphosphine (502 mg, $2.69 \mathrm{mmol}$ ) and anhydrous THF $(10 \mathrm{~mL})$. The solution was cooled to $-78{ }^{\circ} \mathrm{C}$ by a dry ice/ acetone bath, followed by the addition of nBuLi ( $2.5 \mathrm{M}, 1.8 \mathrm{~mL})$, giving a deep-orange color immediately. The mixture was stirred for $30 \mathrm{~min}$ and then another $30 \mathrm{~min}$ at room temperature to ensure the complete generation of $\mathrm{LiPPh}_{2}$. To this solution was slowly added at $-78{ }^{\circ} \mathrm{C}$ L5 (513 $\mathrm{mg}, 2.25 \mathrm{mmol}$ ) in $5 \mathrm{~mL}$ of THF, and the mixture was stirred at this temperature 
for $1 \mathrm{~h}$, followed by a slow increase of temperature to room temperature within $2 \mathrm{~h}$. The solvent was then evaporated in vacuo and the pale-yellow residue dissolved in freshly distilled $\mathrm{CH}_{2} \mathrm{Cl}_{2}(20 \mathrm{~mL})$. The solution was washed with degassed water $(10 \mathrm{~mL} \times 2)$, dried over anhydrous $\mathrm{Na}_{2} \mathrm{SO}_{4}$, and filtered under a nitrogen atmosphere. After evaporation of $\mathrm{CH}_{2} \mathrm{Cl}_{2}$ under vacuum, the product was purified by recrystallization in anhydrous hexane at $-20^{\circ} \mathrm{C}$, giving $\left(\mathrm{P}^{\wedge} \mathrm{N}\right) \mathrm{H}$ as a pale-yellow solid in $57 \%$ yield (429 $\mathrm{mg}, 1.28 \mathrm{mmol})$.

Spectral Data of $\left(P^{\wedge} N\right) H$. MS (EI): $m / z 334\left(\mathrm{M}^{+}\right) .{ }^{1} \mathrm{H}$ NMR (500 MHz, $\left.\mathrm{CDCl}_{3}, 294 \mathrm{~K}\right): \delta 7.39-7.33(\mathrm{~m}, 10 \mathrm{H}), 6.18(\mathrm{~s}, 1 \mathrm{H})$, $3.42(\mathrm{~s}, 2 \mathrm{H}) \cdot{ }^{19} \mathrm{~F}\left\{{ }^{1} \mathrm{H}\right\}$ NMR $\left(470 \mathrm{MHz}, \mathrm{CDCl}_{3}, 294 \mathrm{~K}\right): \delta-62.20$ (s, 3F). ${ }^{31} \mathrm{P}\left\{{ }^{1} \mathrm{H}\right\}$ NMR $\left(202 \mathrm{MHz}, \mathrm{CDCl}_{3}, 294 \mathrm{~K}\right): \delta-14.81(\mathrm{~s}$, 1P). ${ }^{13} \mathrm{C}\left\{{ }^{1} \mathrm{H}\right\}$ NMR (100 MHz, $\left.\mathrm{CDCl}_{3}, 294 \mathrm{~K}\right): \delta 141.8$ (m, broad), $137.3\left(\mathrm{~d}, J_{\mathrm{PC}}=14.2 \mathrm{~Hz}\right), 132.8\left(\mathrm{~d}, J_{\mathrm{PC}}=8.1 \mathrm{~Hz}\right), 132.6\left(\mathrm{~d}, J_{\mathrm{PC}}=\right.$ $19.0 \mathrm{~Hz}), 129.7\left(\mathrm{~d}, J_{\mathrm{PC}}=12.2 \mathrm{~Hz}\right), 128.5\left(\mathrm{~d}, J_{\mathrm{PC}}=6.8 \mathrm{~Hz}\right), 123.1$ $\left(\mathrm{q}, J_{\mathrm{FC}}=267 \mathrm{~Hz}, \mathrm{CF}_{3}\right), 102.9\left(\mathrm{~d}, J_{\mathrm{FC}}=3.4 \mathrm{~Hz}\right), 25.5\left(\mathrm{~d}, J_{\mathrm{PC}}=\right.$ $16.2 \mathrm{~Hz}, \mathrm{CH}_{2}$ ).

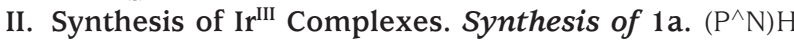
(36.7 mg, $0.11 \mathrm{mmol}$ ) in freshly distilled 2-methoxyethanol (10 $\mathrm{mL}$ ) was transferred to a $25 \mathrm{~mL}$ Schlenk flask charged with $\left[(\text { dfppy })_{2} \operatorname{Ir}(\mu-\mathrm{Cl})\right]_{2}(61 \mathrm{mg}, 0.05 \mathrm{mmol})$ and $\mathrm{Na}_{2} \mathrm{CO}_{3}(53 \mathrm{mg}, 0.5$ $\mathrm{mmol}$ ). The mixture was heated to $120{ }^{\circ} \mathrm{C}$ for $3 \mathrm{~h}$ and then quenched by the addition of water. The precipitate was collected by filtration and washed with diethyl ether and cold methanol in sequence. Separation by flash column chromatography using pure $\mathrm{CH}_{2} \mathrm{Cl}_{2}$ as the eluent gave pale-yellow $1 \mathrm{a}$, which was further purified by recrystallization from a mixture of $\mathrm{CH}_{2} \mathrm{Cl}_{2}$ and hexane at room temperature $(37 \mathrm{mg}, 0.041 \mathrm{mmol}, 41 \%)$.

Spectral Data of 1a. MS (FAB, $\left.{ }^{192} \mathrm{Ir}\right): \mathrm{m} / \mathrm{z} 907(\mathrm{M}+1)+{ }^{+} \mathrm{H}$ $\operatorname{NMR}\left(400 \mathrm{MHz}, \mathrm{CDCl}_{3}, 294 \mathrm{~K}\right): \delta 8.52(\mathrm{~d}, J=5.6 \mathrm{~Hz}, 1 \mathrm{H}), 8.23$ $(\mathrm{dd}, J=8.0$ and $2.8 \mathrm{~Hz}, 1 \mathrm{H}), 7.84(\mathrm{~d}, J=8.0 \mathrm{~Hz}, 1 \mathrm{H}), 7.65(\mathrm{t}, J$ $=8.0 \mathrm{~Hz}, 1 \mathrm{H}), 7.54-7.45(\mathrm{~m}, 3 \mathrm{H}), 7.38-7.32(\mathrm{~m}, 3 \mathrm{H}), 7.12$ $(\mathrm{d}, J=5.6 \mathrm{~Hz}, 1 \mathrm{H}), 6.98(\mathrm{t}, J=8.0 \mathrm{~Hz}, 1 \mathrm{H}), 6.87(\mathrm{t}, J=5.6 \mathrm{~Hz}$, $2 \mathrm{H}), 6.71(\mathrm{t}, J=5.6 \mathrm{~Hz}, 1 \mathrm{H}), 6.55-6.39(\mathrm{~m}, 6 \mathrm{H}), 6.05(\mathrm{dd}, J=$ 8.0 and $2.8 \mathrm{~Hz}, 1 \mathrm{H}), 5.61-5.57(\mathrm{~m}, 1 \mathrm{H}), 4.00(\mathrm{dd}, J=16.0$ and $13.2 \mathrm{~Hz}, 1 \mathrm{H}), 3.64(\mathrm{dd}, J=16.0$ and $4.0 \mathrm{~Hz}, 1 \mathrm{H}) .{ }^{19} \mathrm{~F}\left\{{ }^{1} \mathrm{H}\right\} \mathrm{NMR}$ $\left(470 \mathrm{MHz}, \mathrm{CDCl}_{3}, 294 \mathrm{~K}\right): \delta-59.60(\mathrm{~s}, 3 \mathrm{~F}),-107.33(\mathrm{~s}, 1 \mathrm{~F})$, -108.57 (s, 1F), -110.06 (s, 1F), -110.33 (s, 1F). ${ }^{31} \mathrm{P}\left\{{ }^{1} \mathrm{H}\right\}$ NMR $\left(202 \mathrm{MHz}, \mathrm{CDCl}_{3}, 294 \mathrm{~K}\right): \delta 7.66$ (s, $\left.1 \mathrm{P}\right)$. Anal. Calcd for $\mathrm{C}_{39} \mathrm{H}_{25} \mathrm{~F}_{7} \mathrm{IrN}_{4} \mathrm{P}: \mathrm{N}, 6.46 ; \mathrm{C}, 53.22 ; \mathrm{H}, 3.54$. Found: N, 6.19; C, 53.38; H, 3.47.

Selected Crystal Data of 1a: $\mathrm{C}_{39} \mathrm{H}_{25} \mathrm{~F}_{7} \mathrm{IrN}_{4} \mathrm{P}, M=905.80$, trigonal, space group $P 3_{1}, a=b=13.6175(6) \AA, c=15.2157(7)$ $\AA, \gamma=120^{\circ}, V=2443.53(19) \AA^{3}, Z=3, \rho_{\text {calcd }}=1.847 \mathrm{mg} \mathrm{m}^{-3}$, $F(000)=1326$, crystal size $=0.12 \times 0.12 \times 0.07 \mathrm{~mm}^{3}, \lambda(\mathrm{Mo}$ $\mathrm{K} \alpha)=0.7107 \AA, T=150(2) \mathrm{K}, \mu=4.225 \mathrm{~mm}^{-1}, 20746$ total reflections, 6689 independent reflections with $R_{\text {int }}=0.0519$, $\mathrm{GOF}=0.961$, final R1 $[I>2 \sigma(I)]=0.0319$ and $\mathrm{wR} 2$ (all data) $=0.0618$.

Synthesis of $\mathbf{1 b}$. The preparation of $\mathbf{1 b}$ was conducted following the procedures related to those of $1 \mathrm{a}$; yield $52 \%$

Spectral Data of $1 \mathrm{~b}$. MS (FAB, $\left.{ }^{192} \mathrm{Ir}\right): \mathrm{m} / \mathrm{z} 1019(\mathrm{M}+1)+.{ }^{1} \mathrm{H}$ $\operatorname{NMR}\left(500 \mathrm{MHz}, \mathrm{CDCl}_{3}, 294 \mathrm{~K}\right): \delta 8.37(\mathrm{~d}, J=6.5 \mathrm{~Hz}, 1 \mathrm{H}), 8.27$ $(\mathrm{dd}, J=4.5$ and $2.0 \mathrm{~Hz}, 1 \mathrm{H}), 7.87(\mathrm{~s}, 1 \mathrm{H}), 7.52(\mathrm{t}, J=8.5 \mathrm{~Hz}$, 2H), $7.47(\mathrm{t}, J=7.5 \mathrm{~Hz}, 1 \mathrm{H}), 7.37(\mathrm{t}, J=8.0 \mathrm{~Hz}, 2 \mathrm{H}), 6.94(\mathrm{~d}, J$ $=6.5 \mathrm{~Hz}, 2 \mathrm{H}), 6.83(\mathrm{td}, J=6.5$ and $2.0 \mathrm{~Hz}, 2 \mathrm{H}), 6.70(\mathrm{dd}, J=$ 7.0 and $2.0 \mathrm{~Hz}, 1 \mathrm{H}), 6.55-6.51(\mathrm{~m}, 3 \mathrm{H}), 6.49(\mathrm{dd}, J=7.0$ and $2.0 \mathrm{~Hz}, 1 \mathrm{H}), 6.45-6.40(\mathrm{~m}, 2 \mathrm{H}), 6.05(\mathrm{dd}, J=9.0$ and $2.0 \mathrm{~Hz}$, $1 \mathrm{H}), 5.65-5.62(\mathrm{~m}, 1 \mathrm{H}), 3.97(\mathrm{dd}, J=16.3$ and $13.0 \mathrm{~Hz}, 1 \mathrm{H})$, $3.62(\mathrm{~d}, J=16.3$ and $4.0 \mathrm{~Hz}, 1 \mathrm{H}), 1.32(\mathrm{~s}, 9 \mathrm{H}), 1.20(\mathrm{~s}, 9 \mathrm{H})$. ${ }^{19} \mathrm{~F}\left\{{ }^{1} \mathrm{H}\right\}$ NMR $\left(470 \mathrm{MHz}, \mathrm{CDCl}_{3}, 294 \mathrm{~K}\right): \delta-59.44(\mathrm{~s}, 3 \mathrm{~F})$, $-108.10(\mathrm{~s}, 1 \mathrm{~F}),-109.40(\mathrm{~s}, 1 \mathrm{~F}),-110.38(\mathrm{~s}, 1 \mathrm{~F}),-110.72(\mathrm{~s}$ 1F). ${ }^{31} \mathrm{P}\left\{{ }^{1} \mathrm{H}\right\}$ NMR $\left(202 \mathrm{MHz}, \mathrm{CDCl}_{3}, 294 \mathrm{~K}\right): \delta 7.15$ (s, 1P). Anal. Calcd for $\mathrm{C}_{47} \mathrm{H}_{41} \mathrm{~F}_{7} \mathrm{IrN}_{4} \mathrm{P}$ : N, 5.50; C, 55.45; H, 4.60. Found: $\mathrm{N}$, 5.28; C, 55.28; H, 4.56 .

Synthesis of 2 . A mixture of $\left[(\mathrm{dfpbpy})_{2} \operatorname{Ir}(\mu-\mathrm{Cl})\right]_{2}(72 \mathrm{mg}, 0.05$ mmol), fppzH (22 mg, $0.11 \mathrm{mmol})$, and $\mathrm{Na}_{2} \mathrm{CO}_{3}(53 \mathrm{mg}, 0.5$ $\mathrm{mmol}$ ) was dispersed in $10 \mathrm{~mL}$ of 2 -methoxyethanol and heated to $120{ }^{\circ} \mathrm{C}$ for $1 \mathrm{~h}$. After cooling to room temperature, the addition of excess water resulted in the formation of a yellow precipitate, which was collected by filtration and washed with diethyl ether and cold methanol in sequence. The product was purified by flash column chromatography eluting with $\mathrm{CH}_{2} \mathrm{Cl}_{2}$, followed by recrystallization from a $\mathrm{CH}_{2} \mathrm{Cl}_{2}$ and hexane mixture at room temperature (52 $\mathrm{mg}, 0.058 \mathrm{mmol}, 58 \%$ ).

Spectral Data of 2. MS (FAB, $\left.{ }^{192} \mathrm{Ir}\right): \mathrm{m} / \mathrm{z} 898(\mathrm{M}+1)+.{ }^{1} \mathrm{H}$ $\operatorname{NMR}\left(500 \mathrm{MHz}, \mathrm{CDCl}_{3}, 294 \mathrm{~K}\right): \delta 8.30-8.28(\mathrm{~m}, 2 \mathrm{H}), 8.10(\mathrm{~d}$, $J=7.8 \mathrm{~Hz}, 1 \mathrm{H}), 8.00(\mathrm{t}, J=7.8 \mathrm{~Hz}, 1 \mathrm{H}), 7.85(\mathrm{~d}, J=6.0 \mathrm{~Hz}$, $1 \mathrm{H}), 7.69(\mathrm{~d}, J=6.5 \mathrm{~Hz}, 1 \mathrm{H}), 7.44(\mathrm{~d}, J=6.5 \mathrm{~Hz}, 1 \mathrm{H}), 7.30(\mathrm{dd}$, $J=6.5$ and $2.0 \mathrm{~Hz}, 1 \mathrm{H}), 7.27(\mathrm{~d}, J=6.5 \mathrm{~Hz}, 1 \mathrm{H}), 7.23(\mathrm{dd}, J=$ 6.0 and $2.0 \mathrm{~Hz}, 1 \mathrm{H}), 7.19(\mathrm{~s}, 1 \mathrm{H}), 6.64(\mathrm{ddd}, J=13.0,9.5$, and $2.5 \mathrm{~Hz}, 1 \mathrm{H}), 6.54(\mathrm{ddd}, J=13.0,9.5$, and $2.5 \mathrm{~Hz}, 1 \mathrm{H}), 5.82(\mathrm{dd}$, $J=9.0$ and $2.5 \mathrm{~Hz}, 1 \mathrm{H}), 5.69(\mathrm{~d}, J=9.0$ and $2.5 \mathrm{~Hz}, 1 \mathrm{H}), 1.37$ (s, 9H), $1.36(\mathrm{~s}, 9 \mathrm{H}) \cdot{ }^{19} \mathrm{~F}\left\{{ }^{1} \mathrm{H}\right\}$ NMR $\left(470 \mathrm{MHz}, \mathrm{CDCl}_{3}, 294 \mathrm{~K}\right): \delta$ -60.19 (s, 3F), -109.20 (s, 1F), -110.43 (s, 1F), -111.25 (s, $1 \mathrm{~F}),-112.41(\mathrm{~s}, 1 \mathrm{~F})$. Anal. Calcd for $\mathrm{C}_{39} \mathrm{H}_{33} \mathrm{~F}_{7} \mathrm{IrN}_{5}: \mathrm{N}, 7.81 ; \mathrm{C}$, 52.23; H, 3.71. Found: N, 7.43; C, 52.54; H, 3.57 .

Synthesis of 3. A mixture of $\mathrm{IrCl}_{3} \cdot 3 \mathrm{H}_{2} \mathrm{O}(106 \mathrm{mg}, 0.30$ $\mathrm{mmol}$ ) and (fppz)H (128 mg, $0.60 \mathrm{mmol})$ in $20 \mathrm{~mL}$ of diethylene glycol monomethyl ether was heated to $140^{\circ} \mathrm{C}$ for $12 \mathrm{~h}$. After cooling to room temperature, $\left(\mathrm{P}^{\wedge} \mathrm{N}\right) \mathrm{H}(100 \mathrm{mg}, 0.30 \mathrm{mmol})$ and sodium acetate $(246 \mathrm{mg}, 3.00 \mathrm{mmol}$ ) were added, the mixture was stirred at room temperature for $1 \mathrm{~h}$ and kept at $160{ }^{\circ} \mathrm{C}$ for $16 \mathrm{~h}$, and the solution was concentrated to $5 \mathrm{~mL}$ under vacuum. The addition of water resulted in a colorless precipitate, which was collected by filtration, washed with cold methanol, and dried under vacuum. Further purification was conducted by silica gel column chromatography eluting with a $1: 1$ mixture of ethyl acetate and hexane, followed by recrystallization from a mixture of $\mathrm{CH}_{2} \mathrm{Cl}_{2}$ and hexane to afford a white crystalline solid (59.2 mg, $0.03 \mathrm{mmol}, 21 \%$ )

Spectral Data of 3. MS (FAB, $\left.{ }^{192} \mathrm{Ir}\right): \mathrm{m} / \mathrm{z} 951(\mathrm{M}+1)+.{ }^{1} \mathrm{H}$ $\operatorname{NMR}\left(500 \mathrm{MHz}, \mathrm{CDCl}_{3}, 294 \mathrm{~K}\right): \delta 7.72-7.66(\mathrm{~m}, 2 \mathrm{H}), 7.57-7.53$ $(\mathrm{m}, 3 \mathrm{H}), 7.46(\mathrm{t}, J=7.0 \mathrm{~Hz}, 1 \mathrm{H}), 7.30-7.23(\mathrm{~m}, 5 \mathrm{H}), 7.08-7.04$ $(\mathrm{m}, 3 \mathrm{H}), 6.92(\mathrm{~d}, J=6.0 \mathrm{~Hz}, 1 \mathrm{H}), 6.89-6.85(\mathrm{~m}, 3 \mathrm{H}), 6.74(\mathrm{~s}$, $1 \mathrm{H}), 6.69(\mathrm{~s}, 1 \mathrm{H}), 6.37(\mathrm{~s}, 1 \mathrm{H}), 4.33(\mathrm{dd}, J=15.0$ and $6.5 \mathrm{~Hz}$, $1 \mathrm{H}), 3.61(\mathrm{t}, J=15.0 \mathrm{~Hz}, 1 \mathrm{H}) .{ }^{19} \mathrm{~F}\left\{{ }^{1} \mathrm{H}\right\} \mathrm{NMR}\left(470 \mathrm{MHz}, \mathrm{CDCl}_{3}\right.$, $294 \mathrm{~K}): \delta-60.11$ (s, 3F), -60.53 (s, 3F), -60.85 (s, 3F). ${ }^{31} \mathrm{P}\left\{{ }^{1} \mathrm{H}\right\}$ NMR $\left(202 \mathrm{MHz} \mathrm{CDCl}_{3}, 294 \mathrm{~K}\right): \delta 4.71$ (s, 1P). Anal. Calcd for $\mathrm{C}_{35} \mathrm{H}_{23} \mathrm{~F}_{9} \mathrm{IrN}_{8} \mathrm{P}: \mathrm{N}, 11.80 ; \mathrm{C}, 44.26 ; \mathrm{H}, 2.44$. Found: N, 12.05; C, 43.90; H, 2.84.

Selected Crystal Data of 3: $\mathrm{C}_{36.5} \mathrm{H}_{26} \mathrm{Cl}_{3} \mathrm{~F}_{9} \mathrm{IrN}_{8} \mathrm{P}, \quad M=$ 1077.17, monoclinic, space group $P 2_{1} c, a=12.2981$ (5) $\AA, b=$ 19.0081(9) $\AA, c=17.3305(8) \AA, \beta=102.658(1)^{\circ}, V=3952.8(3)$ $\AA^{3}, Z=4, \rho_{\text {calcd }}=1.810 \mathrm{mg} \mathrm{m}^{-3}, F(000)=2100$, crystal size $=$ $0.33 \times 0.22 \times 0.10 \mathrm{~mm}^{3}, \lambda($ Mo K $\alpha)=0.7107 \AA, T=150(2) \mathrm{K}$, $\mu=3.704 \mathrm{~mm}^{-1}, 30293$ total reflections, 9081 independent reflections with $R_{\text {int }}=0.0509, \mathrm{GOF}=1.034$, final $\mathrm{R} 1[I>2 \sigma(I)]$ $=0.0386$ and wR2 (all data) $=0.0883$.

$X$-ray Diffraction Studies. Single-crystal X-ray diffraction data of $1 \mathbf{a}$ and 3 were measured on a Bruker SMART Apex CCD diffractometer using $($ Mo $K \alpha)$ radiation $(\lambda=0.71073 \AA)$. The data collection was executed using the SMART program. Cell refinement and data reduction were performed with the SAINT program. The structure was determined using the SHELXTL/PC program and refined using full-matrix least squares. A crystalline sample of 3 was crystallized with 1.5 equiv of $\mathrm{CH}_{2} \mathrm{Cl}_{2}$ in the unit cell.

Spectral and Dynamic Measurement. Steady-state absorption and emission spectra were recorded by a Hitachi (U-3310) spectrophotometer and an Edinburgh (FS920) fluorimeter, respectively. Emission quantum yields were measured at excitation wavelength $\lambda_{\mathrm{ex}}=350 \mathrm{~nm}$ in $\mathrm{CH}_{2} \mathrm{Cl}_{2}$ at room temperature. In this approach, quinine sulfate with an emission yield of $\Phi \sim$ $0.54 \pm 0.2$ in a $1.0 \mathrm{~N}$ sulfuric acid solution served as the standard to calculate the emission quantum yield. Lifetime studies were performed by an Edinburgh FL 900 photon count- 
ing system with a hydrogen-filled or a nitrogen lamp as the excitation source. Data were analyzed using a nonlinear leastsquares procedure in combination with an iterative convolution method. The emission decays were analyzed by the sum of exponential functions, which allows partial removal of the instrument time broadening and consequently renders a temporal resolution of $\sim 200 \mathrm{ps}$.

Computational Methodology. Density functional theory (DFT) calculations on the electronic singlet state of complexes 1-3 were carried out using a hybrid Hartree-Fock/DFT model (PBE1PBE) based on the Perdew-Burke-Erzenrhof (PBE) functional (17). A double- $\varsigma$ quality basis set consisting of Hay and Wadt's effective core potentials (LANL2DZ) (18) was employed for the Ir atom and a $6-31 \mathrm{G}^{*}$ basis set for the $\mathrm{H}, \mathrm{C}, \mathrm{N}$, and $\mathrm{F}$ atoms. A relativistic effective core potential replaced the inner core electrons of Ir III, leaving the outer core $\left(5 s^{2} 5 p^{6}\right)$ electrons and the $5 d^{6}$ valence electrons. Time-dependent DFT (TDDFT) calculations (19) for the $\mathrm{S}_{0} \rightarrow \mathrm{S}_{\mathrm{n}}$ and $\mathrm{S}_{0} \rightarrow \mathrm{T}_{1}$ transitions using the PBE1PBE functional were then performed based on the obtained geometries from the geometry optimization in the ground state. Typically, the lowest triplet and 10 singlet roots of the nonhermitian eigenvalue equations were obtained to determine the vertical excitation energies. Oscillator strengths were deduced from the dipole transition matrix elements (for singlet states only). An unpaired spin-density $\alpha-\beta$ distribution is also calculated and discussed. All calculations were carried out using Gaussian 03 (20).

Device Fabrication and Characterization. OLEDs were fabricated on indium-tin oxide (ITO)-coated glass substrates with multiple organic layers sandwiched between the transparent bottom ITO anode and the top metal cathode. The multilayer device structure was fabricated by thermal evaporation in a stainless steel chamber with a base pressure of $\leq 10^{-6}$ Torr, as well as in a single pumpdown without breaking the vacuum. The deposition rate of organic layers was kept at $\sim 0.2 \mathrm{~nm} \mathrm{~s}^{-1}$. The active area of the device is $1 \times 1 \mathrm{~mm}^{2}$, as defined by the shadow mask for cathode deposition. The current-voltagebrightness $(I-V-L)$ characteristics of devices were measured using an Agilent 4155B semiconductor parameter analyzer and a silicon photodiode calibrated with a Photo Research PR-650 spectroradiometer. EL spectra of devices were collected by a calibrated CCD spectrograph.

\section{RESULTS AND DISCUSSION}

Synthesis and Characterization. The newly designed $\left(\mathrm{P}^{\wedge} \mathrm{N}\right) \mathrm{H}$ chelate, 5-(diphenylphosphinomethyl)-3-(trifluoromethyl)pyrazole, was obtained using a multistep protocol starting from a Claisen condensation involving 4-(2tetrahydropyranyloxy)-2-butanone(L1) and ethyl trifluoroacetate, followed by execution of pyrazole ring closure using hydrazine hydrate, deprotection of the terminal hydroxyl group, bromination employing $\mathrm{PBr}_{3}$, and, finally treatment with the in situ generated $\mathrm{LiPPh}_{2}$ reagent. This synthetic sequence is schematically depicted in Scheme 1, while the detailed reaction conditions and chemical reagents employed for each individual step are elaborated in the Experimental Section. We propose that this newly designed $\left(\mathrm{P}^{\wedge} \mathrm{N}\right) \mathrm{H}$ ligand offers several advantages, including the following: (i) It is capable of forming a rigid and stable five-membered metal-chelate bonding interaction. (ii) The greater $\pi$ acidity of phosphine stabilizes the metal $\mathrm{d}_{\pi}$ orbitals, which, in turn, reduces the participation of the MLCT transition at the lowest-energy excited state, which could otherwise produce a bathochromic shift of phosphorescence. (iii) The greater ligand field strength of the phosphine ligand (21) could
Scheme 1. Schematic Synthetic Diagram ${ }^{a}$

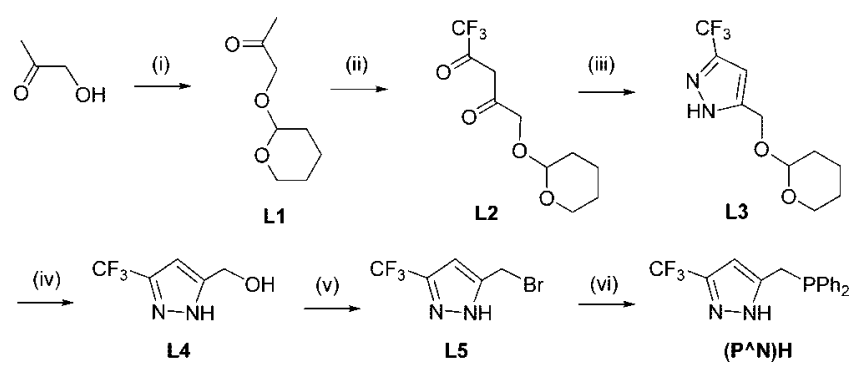

a (i) 3,4-Dihydro-2H-pyran, room temperature. (ii) $\mathrm{NaOEt}$, ethyl trifluoroacetate, THF, $50{ }^{\circ} \mathrm{C}$. (iii) $\mathrm{N}_{2} \mathrm{H}_{4} \cdot \mathrm{H}_{2} \mathrm{O}, \mathrm{EtOH}$, reflux. (iv) $\mathrm{HCl}$, $\mathrm{EtOH}$, room temperature. (v) $\mathrm{PBr}_{3}$, ether, room temperature. (vi) $\mathrm{LiPPh}_{2}$, $\mathrm{THF},-78^{\circ} \mathrm{C}$.

Scheme 2. Structural Drawing of Complexes $1-3$

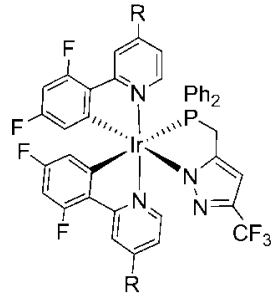

$\mathrm{R}=\mathrm{H}(\mathbf{1} \mathrm{a}) ; \mathrm{R}={ }^{\mathrm{t}} \mathrm{Bu}(\mathbf{1 b})$

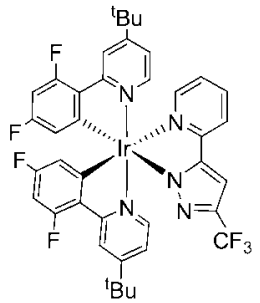

(2)

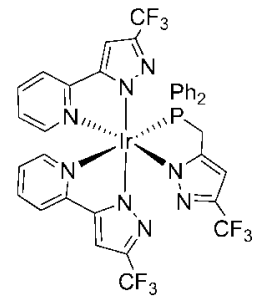

(3) destabilize the metal-centered dd excited state and thus discourage the thermal population to this deactivation state, which could otherwise cause a rapid quench of emission. (iv) There is effective suppression of $\pi$-orbital participation of the $\left(\mathrm{P}^{\wedge} \mathrm{N}\right)$ chelate at both the highest occupied molecular orbital (HOMO) and lowest unoccupied molecular orbital (LUMO) of resulting Ir III complexes. (v) There is improved chemical reactivity at the pyrazole site of the $\left(\mathrm{P}^{\wedge} \mathrm{N}\right) \mathrm{H}$ chelate, which allowed the preparation of Ir ${ }^{\mathrm{III}}$ complexes under less severe conditions.

Among the above-mentioned superiorities, (ii) may conversely raise the adverse effect because of the elongation of the radiative lifetime upon increasing $\pi \pi^{*}$ contribution, such that the emission may be more likely subjected to other quenching processes. As supported by the results elaborated in the following sections, such inferiority can be compensated for by the advantages (i), (iii), and (iv) specified above.

As shown in Scheme 2, this $\left(\mathrm{P}^{\wedge} \mathrm{N}\right) \mathrm{H}$ chelate showed good reactivity with $\mathrm{Ir}^{\mathrm{III}}$ reagents in giving high-efficiency, room temperature phosphors. As such, the treatment of $\left(\mathrm{P}^{\wedge} \mathrm{N}\right) \mathrm{H}$ with dimer $\left[(\mathrm{dfppy})_{2} \operatorname{Ir}(\mu-\mathrm{Cl})\right]_{2}$ and with its tert-butyl-substituted derivative $\left[(\mathrm{dfpbpy})_{2} \operatorname{Ir}(\boldsymbol{\mu}-\mathrm{Cl})\right]_{2}$ afforded the heteroleptic $\operatorname{Ir}^{\mathrm{III}}$ complexes $\left[\operatorname{Ir}(\mathrm{dfppy})_{2}\left(\mathrm{P}^{\wedge} \mathrm{N}\right)\right](\mathbf{1 a})$ and $\left[\operatorname{Ir}(\mathrm{dfpbpy})_{2}\left(\mathrm{P}^{\wedge} \mathrm{N}\right)\right]$ (1) $)$, respectively. In order to provide reference for the comparative investigation, the analogous [Ir(dfpbpy) 2 (fppz)] (2) was also prepared. The employed synthetic procedure is akin to the literature regarding cyclometalated dimer complexes of formula $\left[\left(\mathrm{C}^{\wedge} \mathrm{N}\right)_{2} \operatorname{Ir}(\mu-\mathrm{Cl})\right]_{2}$ and chelates such as pyridyl azolate (22) and many others (23). Finally, the third emissive complex, namely, $\left[\operatorname{Ir}(\mathrm{fppz})_{2}\left(\mathrm{P}^{\wedge} \mathrm{N}\right)\right](3)$, which showed the existence of two fppz chromophoric chelates but no traditional cyclometalated chelates such as dfppy or dfbppy, was alternatively prepared by the treatment of $\mathrm{IrCl}_{3}$ with 2 


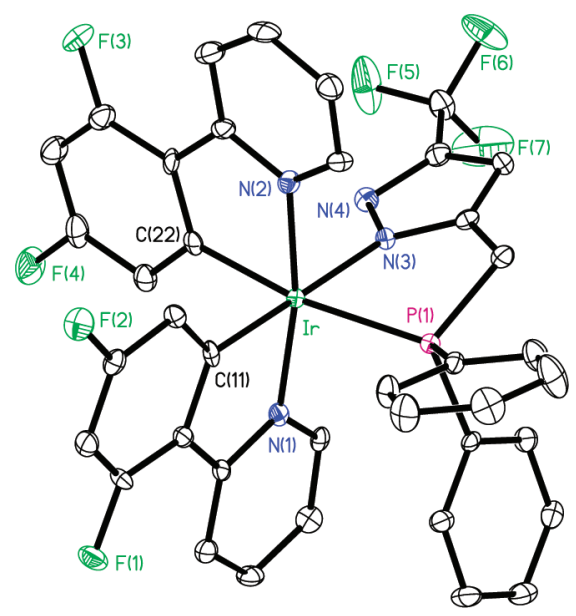

FIGURE 1. ORTEP diagram of $1 \mathrm{a}$ with thermal ellipsoids shown at the $30 \%$ probability level. Selected bond lengths $(\AA)$ : $\operatorname{Ir}-\mathrm{C}(11)=$ $2.009(5), \operatorname{Ir}-\mathrm{C}(22)=2.036(5), \operatorname{Ir}-\mathrm{N}(1)=2.044(5), \operatorname{Ir}-\mathrm{N}(2)=2.057(5)$, $\operatorname{Ir}-\mathrm{N}(3)=2.148(5), \operatorname{Ir}-\mathrm{P}(1)=2.353(2)$.

equiv of (fppz)H and then with 1 equiv of $\left(\mathrm{P}^{\wedge} \mathrm{N}\right) \mathrm{H}$ sequentially. All of these complexes were thoroughly characterized by mass spectrometry, multinuclear NMR spectroscopies, UV/vis spectral measurement, and elemental analyses, while single-crystal X-ray diffraction studies on $\mathbf{1 a}$ and $\mathbf{3}$ were carried out to reveal their exact formula and geometrical arrangement.

As indicated in Figure 1, the structure of 1 a reveals a slightly distorted octahedral geometry. The dfppy ligands show trans $-\mathrm{Ir}-\mathrm{N}$ bond lengths of 2.044(5) and 2.057(5) $\AA$, which are within the normal ranges expected for analogous cyclometalated IIIII complexes (24). Carbon atoms C(11) and $\mathrm{C}(22)$ on the dfppy ligands are cis to one another, and their respective Ir $-\mathrm{C}$ distances, 2.009(5) and 2.036(5) $\AA$, are notable longer than those of the acetylacetonate analogues (25), particularly the Ir-C vector located trans to the $\mathrm{PPh}_{2}$ segment, because of the stronger $\pi$-accepting property (trans effect). The metallacycle of the $\left(\mathrm{P}^{\wedge} \mathrm{N}\right)$ chelate is significantly puckered, with the middle methylene being deviated from the extension of the $\mathrm{Ir}-\mathrm{P}-\mathrm{N}$ plane by $0.872 \AA$, due to the geometrical restriction imposed by both $\mathrm{sp}^{3}$-hybridized phosphorus and methylene linkages.

In sharp contrast, the fppz chromophores in 3 exhibit an unusual spatial arrangement not observed for dfppy chelates in 1a. As shown in Figure 2, the pyridyl groups are now situated cis to one another, while their pyrazolate groups are located at the trans disposition. This distinctive arrangement ensures the $\mathrm{PPh}_{2}$ groups residing trans to one pyridyl group of the fppz chelate and shows a shortened Ir-P distance of 2.279(1) $\AA$ versus that observed in $\mathbf{1 a}$ of 2.353(2) $\AA$, for which the same $\mathrm{PPh}_{2}$ group is trans to a phenyl group. Despite this difference, both complexes $\mathbf{1 a}$ and $\mathbf{3}$ reveal a meridional coordination for all ligating anions, i.e., both phenyl and pyrazolate groups, as well as for the neutral donor segments, i.e., both pyridyl and $\mathrm{PPh}_{2}$ units. The driving force causing this meridional ligating arrangement is pending resolution; however, for 3 , it could be due to a reduced spatial repulsion between the bulky $\mathrm{CF}_{3}$-substituted pyrazolates in the meridional arrangement of $\mathbf{3}$, where a
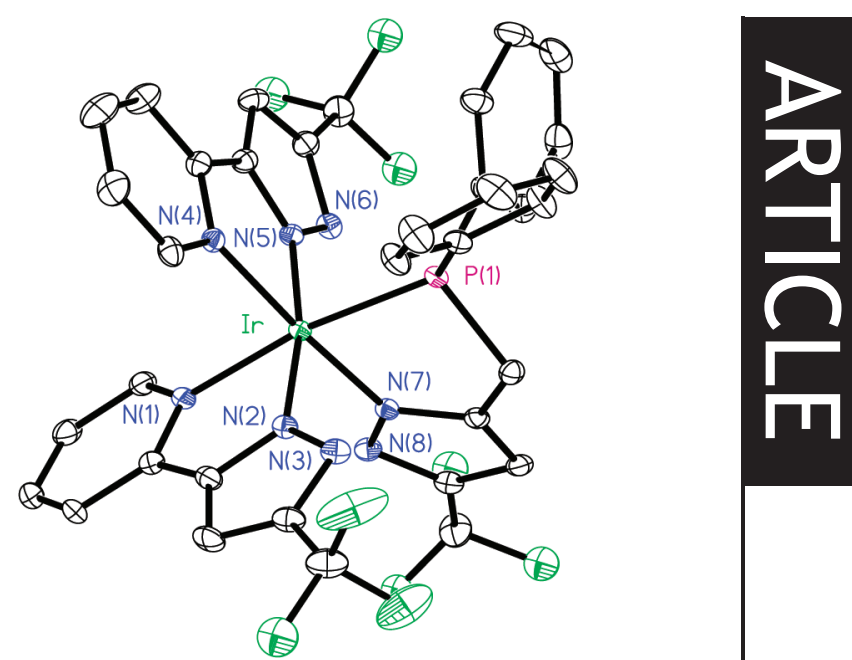

FIGURE 2. ORTEP diagram of 3 with thermal ellipsoids shown at the $30 \%$ probability level. Selected bond lengths $(\AA): \operatorname{Ir}-N(1)=2.109(4)$, $\operatorname{Ir}-\mathrm{N}(2)=2.022(4), \operatorname{Ir}-\mathrm{N}(4)=2.084(4), \operatorname{Ir}-\mathrm{N}(5)=2.020(3), \operatorname{Ir}-\mathrm{N}(7)$ $=2.032(4), \operatorname{Ir}-\mathrm{P}(1)=2.279(1)$.

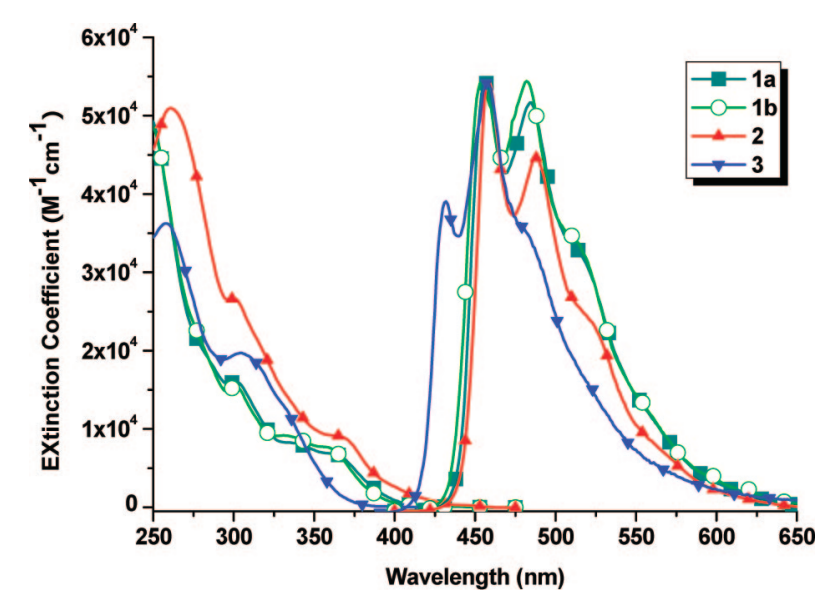

FIGURE 3. Absorption spectra and normalized emission spectra of complexes $1-3$ recorded in a $\mathrm{CH}_{2} \mathrm{Cl}_{2}$ solution at room temperature.

similar explanation has been given to account for the meridional orientation for $\left[\mathrm{Ir}(\mathrm{fppz})_{3}\right]$ (13). In contrast, its facial isomer would have these pyrazolate groups located at the same triangular face, which is far more congested than that at the meridional position.

Photophysical Properties. Figure 3 shows the UV/ vis absorption and emission spectra of the titled complexes in $\mathrm{CH}_{2} \mathrm{Cl}_{2}$. In general, the dominant absorption band in the spectral region of $\leq 340 \mathrm{~nm}$, for which $\varepsilon$ values at the absorption maximum are calculated to be $\sim 10^{4} \mathrm{M}^{-1} \mathrm{~cm}^{-1}$, is attributed to the ILCT transition involving dfppy, dfpbpy, and fppz fragments and, to a small extent, the LLCT associated with the $\mathrm{P}^{\wedge} \mathrm{N}$ chelate. The broad band at longer wavelengths of $\sim 350-370 \mathrm{~nm}$ for $\mathbf{1 a}, \mathbf{1} \mathbf{b}$, and $\mathbf{2}$, as supported by their relatively lower extinction coefficients, is assigned to the tail of the ILCT transition overlapping with the MLCT transition in the singlet manifold. The even lower lying band that appears in the region of $>380 \mathrm{~nm}$ and becomes a shoulder extended to $\sim 400 \mathrm{~nm}$, as supported by their lower extinction coefficients of $\leq 1000 \mathrm{M}^{-1} \mathrm{~cm}^{-1}$, is reasonably assigned to ${ }^{3} \pi \pi$, mixed with significant ${ }^{3}$ MLCT transition 
character, which becomes partially allowed because of strong spin-orbit coupling. It is important to note that all absorption bands of $\mathbf{2}$ have a significant gain in absorptivity and reveal a slight red shift compared to those of $\mathbf{1 a}$ and $\mathbf{1} \mathbf{b}$, manifesting the significant influence upon switching the $\mathrm{PPh}_{2}$ group of the $\mathrm{P}^{\wedge} \mathrm{N}$ chelate in $\mathbf{1 a}$ (or $\mathbf{1} \mathbf{b}$ ) by the pyridyl group of the fppz ligand in 2 . In comparison to the $\mathrm{P}^{\wedge} \mathrm{N}$ chelate, the much extended $\pi$ conjugation and the better electron donation for the fppz ligand in $\mathbf{2}$ are two key factors that cause the spectral red shift. On the basis of the same $\mathrm{P}^{\wedge} \mathrm{N}$ chelate, further reduction of the absorptivity and blueshifting of the lowest-energy absorption band are observed in $\mathbf{3}$ (cf. $\mathbf{1 a}$ or $\mathbf{1 b}$ ), the result of which is obviously due to the increased $\pi \pi^{*}$ energy gap for its true-blue-emitting fppz chromophores. Supplementary support of these viewpoints and corresponding assignments are provided in the following section of molecular frontier orbital analyses and associated energy gaps.

As for the emission spectra, complexes $1 \mathrm{a}, \mathbf{1 b}$, and $\mathbf{2}$ all exhibit vibronically progressive emissions with first peak wavelengths around $450-458 \mathrm{~nm}$ in $\mathrm{CH}_{2} \mathrm{Cl}_{2}$ at room temperature. The spectral profile is reminiscent of other Ir $^{\text {III }}$ complexes having a dfppy cyclometalated chelate and is also comparable to that of the cationic "blue-emitting" Ir" complexes with strongly $\pi$-accepting ligands (26). Variation of the ancillary ligand, such as substitution of $\mathrm{PPh}_{2}$ by the pyridyl group for $\mathbf{2}$ (cf. $\mathbf{1 a}$ and $\mathbf{1 b}$ ), shows a small bathochromic shift of the emission peak wavelengths as well as a slight diminution of the higher order vibronic bands. The results indicate that both ancillary chelates (i.e., $\mathrm{P}^{\wedge} \mathrm{N}$ vs fppz) play a minor role in the lower-lying transitions that are mainly associated with the dfppy and dfpbpy chromophores. Nevertheless, despite their acting as an ancillary-like chelate, which may prohibit their capability in course tuning, they are apparently suited to fine-tune the spectral properties toward authentic blue colorant and to improve the emission quantum yield of the Ir IIII complexes.

In yet another approach, 3 possessing two fppz and one $\mathrm{P}^{\wedge} \mathrm{N}$ chelates gives rise to three emission peak maxima at 431,458 , and $482 \mathrm{~nm}$ in a degassed $\mathrm{CH}_{2} \mathrm{Cl}_{2}$ solution. The corresponding emission profile is reminiscent of the osmium(II) carbonyl complexes, $\left[\mathrm{Os}(\mathrm{fppz})_{2}(\mathrm{CO})_{2}\right](11)$, showing unique ligand-centered $\pi \pi^{*}$ vibronic characteristics. We thus successfully duplicate the true-blue phosphorescence of $\left[\mathrm{Os}(\mathrm{fppz})_{2}(\mathrm{CO})_{2}\right]$ based on the isoelectronic $\mathrm{Ir}^{\mathrm{III}}$ metal platform with remarkable room temperature quantum efficiency. It is also worth noting that, in sharp contrast to the fppz of $\mathbf{2}$ that serves as the ancillary chelate, the fppz ligand in 3 now acts as the main emitting chromophore; the switch of the emission moiety is mainly attributed to the attachment of the third $\mathrm{P}^{\wedge} \mathrm{N}$ ancillary ligand in 3 , which has an even larger energy gap than fppz.

We then carried out a DFT approach with the aim of gaining more insight into the photophysics of the titled complexes. Figures 4 and 5 depict the frontier orbitals that are mainly involved in the low-lying $\mathrm{S}_{0} \rightarrow \mathrm{S}_{1}$ and $\mathrm{S}_{0} \rightarrow \mathrm{T}_{1}$ transitions. Pertinent orbital descriptions and the energy

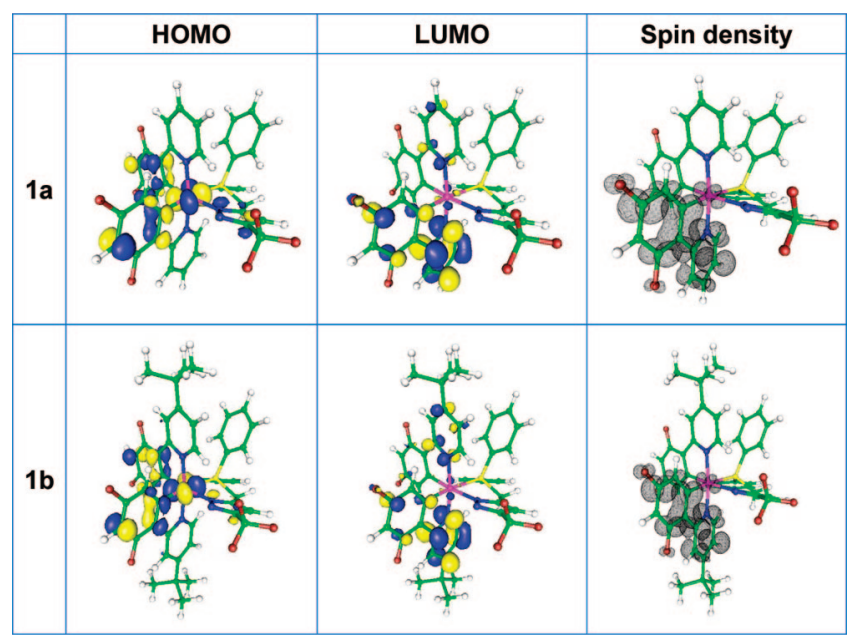

FIGURE 4. Selected molecular orbital diagrams of $1 \mathrm{a}$ and $1 \mathrm{~b}$ at their $\mathrm{S}_{0}$ geometry and the spin-density distribution of the triplet electronic configuration. Other orbitals involved in the $S_{0} \rightarrow S_{1}$ and/or $T_{1}$ transition of complexes $1 \mathrm{a}$ and $1 \mathrm{~b}$ are depicted in the Supporting Information.

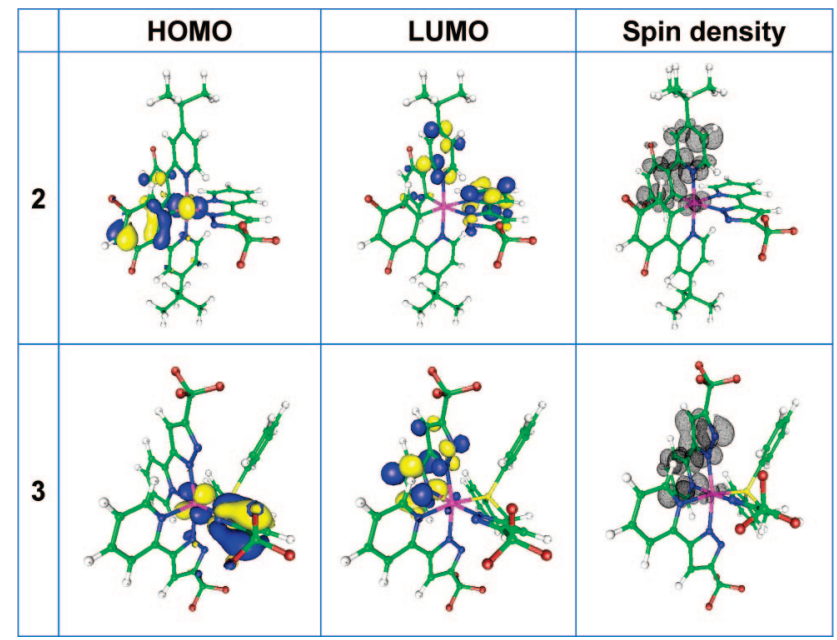

FIGURE 5. Selected molecular orbital diagrams of 2 and 3 at their $\mathrm{S}_{0}$ geometry and the spin-density distribution of the triplet electronic configuration. The other orbitals involved in the $S_{0} \rightarrow S_{1}$ and/or $T_{1}$ transition of complexes 2 and 3 are depicted in the Supporting Information.

gaps for all four complexes are listed in Table 2. The data of computational approaches compiled in Table 2 can be summarized into several remarks. First, the calculated Franck-Condon vertical $S_{1}$ energy levels for all of these complexes are qualitatively consistent with the respective $0-0$ onsets of the absorption $\left(S_{1}\right)$, while the $T_{1}$ level is in agreement with the onset of phosphorescence, if the effect of the solvent dipole relaxation is neglected. Thus, the theoretical level adopted here should be suitable for studying the photophysical properties of these complexes in a qualitative manner. Second, both the $S_{1}$ and $T_{1}$ states of $\mathbf{1 a}, \mathbf{1} \mathbf{b}$, and 2 share the same pattern, consisting of the lowest $\pi \pi^{*}$ transition on the cyclometalated chelates, to a small extent, mixed with LLCT [azolate of $\mathrm{P}^{\wedge} \mathrm{N}$ (or fppz) to the pyridyl group of dfppy chelates] and MLCT (metal to the pyridyl group of the dfppy chelate), although the ancillary ligand is not the same ( $\mathrm{P}^{\wedge} \mathrm{N}$ vs fppz; see Table 2 and the Supporting Information for detailed assignments). 
Table 1. Photophysical Properties of Ir ${ }^{\mathrm{III}}$ Complexes $1 \mathrm{a}-3$ in Degassed $\mathrm{CH}_{2} \mathrm{Cl}_{2}$ at Room Temperature

\begin{tabular}{|c|c|c|c|c|c|c|}
\hline & abs $\lambda_{\max } / \mathrm{nm}\left(\epsilon \times 10^{-3}\right)$ & $\mathrm{em} \lambda_{\max } / \mathrm{nm}$ & $\Phi(\%)$ & $\tau_{\text {obs }}(\mu \mathrm{s})$ & $k_{\mathrm{r}}$ & $k_{\mathrm{nr}}$ \\
\hline $1 \mathrm{a}$ & 301 (16.4), $338(8.2), 365$ (6.7) & $456,484,512$ & 71.8 & 3.98 & $1.8 \times 10^{5}$ & $7.1 \times 10^{4}$ \\
\hline $1 b$ & $301(16.1), 332(9.2), 359(7.7)$ & $455,482,516$ & 72.3 & 3.83 & $1.9 \times 10^{5}$ & $7.1 \times 10^{4}$ \\
\hline 3 & 258 (36.3), 305 (19.7), $331(13.0)$ & $\begin{array}{l}431,458,482 \\
(432,459,486)^{a} \\
{[434,455,480]^{b}}\end{array}$ & $\begin{array}{l}2.4 \\
(25.1) \\
{[35.1]}\end{array}$ & $\begin{array}{l}0.68 \\
(18.7) \\
{[18.4]}\end{array}$ & $\begin{array}{l}3.5 \times 10^{4} \\
\left(1.3 \times 10^{4}\right) \\
{\left[1.9 \times 10^{4}\right]}\end{array}$ & $\begin{array}{l}1.4 \times 10^{6} \\
\left(4.0 \times 10^{4}\right) \\
{\left[3.5 \times 10^{4}\right]}\end{array}$ \\
\hline
\end{tabular}

${ }^{a}$ Data recorded in UGH2 as the host material at a concentration of $6 \mathrm{wt} \% .{ }^{b}$ Data recorded in $\mathrm{CzSi}$ as the host material at a concentration of 6 wt $\% .{ }^{c} k_{\mathrm{r}}=\Phi / \tau_{\mathrm{obs}}$, and $k_{\mathrm{nr}}=\left(1 / \tau_{\mathrm{obs}}\right)-k_{\mathrm{r}}$.

Table 2. Transitions of $1 \mathrm{a}, 1 \mathrm{~b}, 2$, and 3 Calculated by the TDDFT Method and the Polarized Continuum Model

\begin{tabular}{|c|c|c|c|c|c|}
\hline & states & $\lambda(\mathrm{nm})$ & $f$ & assignments & $\begin{array}{c}\text { MLCT } \\
(\%)\end{array}$ \\
\hline $1 \mathrm{a}$ & $\mathrm{T}_{1}$ & 437.3 & 0 & $\begin{array}{l}\text { HOMO- } \rightarrow \text { LUMO }(+26 \%) \\
\text { HOMO-3 } \rightarrow \text { LUMO }(22 \%) \\
\text { HOMO } \rightarrow \text { LUMO }(15 \%) \\
\text { HOMO-2 } \rightarrow \text { LUMO }(11 \%) \\
\text { HOMO-3 } \rightarrow \text { LUMO }+4(6 \%)\end{array}$ & 11.10 \\
\hline & $\mathrm{S}_{1}$ & 363.4 & 0.0225 & $\begin{array}{l}\text { HOMO } \rightarrow \text { LUMO }(+61 \%) \\
\text { HOMO } \rightarrow \text { LUMO+1 }(16 \%) \\
\text { HOMO-1 } \rightarrow \text { LUMO }(13 \%)\end{array}$ & 24.13 \\
\hline $1 \mathrm{~b}$ & $\mathrm{~T}_{1}$ & 427.8 & 0 & $\begin{array}{l}\text { HOMO }-1 \rightarrow \text { LUMO }(+20 \%) \\
\text { HOMO }-3 \rightarrow \text { LUMO }(15 \%) \\
\text { HOMO } \rightarrow \text { LUMO }(+12 \%) \\
\text { HOMO-2 } \rightarrow \text { LUMO }(+10 \%) \\
\text { HOMO-3 } \rightarrow \text { LUMO }+4(9 \%) \\
\text { HOMO }-1 \rightarrow \text { LUMO }+1(+7 \%) \\
\text { HOMO }-3 \rightarrow \text { LUMO }+1(6 \%)\end{array}$ & 11.34 \\
\hline & $S_{1}$ & 357.4 & 0.0335 & $\begin{array}{l}\text { HOMO } \rightarrow \text { LUMO }(+49 \%) \\
\text { HOMO } \rightarrow \text { LUMO }+1(+30 \%) \\
\text { HOMO- } 1 \rightarrow \text { LUMO }(+10 \%)\end{array}$ & 24.30 \\
\hline 2 & $\mathrm{~T}_{1}$ & 436.5 & 0 & $\begin{array}{l}\mathrm{HOMO}-4 \rightarrow \text { LUMO }+1(20 \%) \\
\mathrm{HOMO} \rightarrow \text { LUMO }+1(+17 \%) \\
\mathrm{HOMO} \rightarrow \text { LUMO }(17 \%) \\
\mathrm{HOMO}-4 \rightarrow \mathrm{LUMO}(+13 \%) \\
\mathrm{HOMO} \rightarrow \text { LUMO+2 }(+9 \%) \\
\mathrm{HOMO}-2 \rightarrow \text { LUMO }+2(8 \%)\end{array}$ & 17.39 \\
\hline & $S_{1}$ & 375 & 0.0356 & $\begin{array}{l}\mathrm{HOMO} \rightarrow \text { LUMO }(+59 \%) \\
\mathrm{HOMO} \rightarrow \mathrm{LUMO}+1(33 \%)\end{array}$ & 31.19 \\
\hline 3 & $\mathrm{~T}_{1}$ & 419.9 & 0 & $\begin{array}{l}\text { HOMO }-2 \rightarrow \text { LUMO }(+36 \%) \\
\text { HOMO }-4 \rightarrow \text { LUMO }(18 \%) \\
\text { HOMO-3 } \rightarrow \text { LUMO }(18 \%) \\
\text { HOMO-2 } \rightarrow \text { LUMO }+2(+12 \%) \\
\text { HOMO } \rightarrow \text { LUMO }(+10 \%)\end{array}$ & 9.78 \\
\hline & $\mathrm{S}_{1}$ & 370.7 & 0.0029 & $\mathrm{HOMO} \rightarrow \mathrm{LUMO}(+93 \%)$ & 19.02 \\
\hline
\end{tabular}

On the other hand, $S_{1}$ and $T_{1}$ of 3 are attributed to MLCT (metal to the pyridyl of the fppz ligand) mixing with ILCT/ LLCT (azolate of both $\mathrm{fppz}$ and $\mathrm{P}^{\wedge} \mathrm{N}$ to the pyridyl group of one fppz chelate). One can thus intuitively expect that $\mathbf{3}$ reveals different origins of higher-lying frontier orbitals (regarding the $\pi \pi^{*}$ transition) from the rest of the complexes studied, and a larger absorption gap of 3 is anticipated because the triplet orbital energy of the $\mathrm{CF}_{3}$-substituted pyrazolate moiety is lower than the difluorophenyl group of cyclometalated chelates (see Figure 6). Third, MLCT contri-

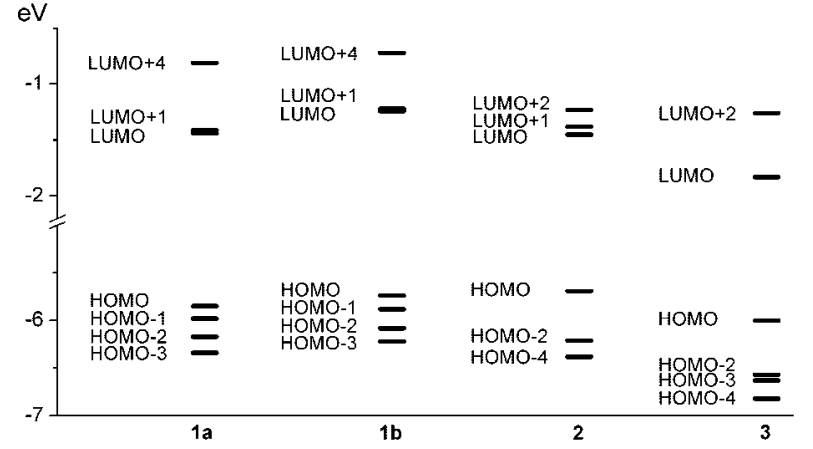

FIGURE 6. Schematic energy level diagram and calculated compositions for molecular orbitals that involved in the $\mathrm{T}_{1}$ transition. $1 \mathrm{a}$ : HOMO, $\mathrm{d}_{\pi}[\mathrm{Ir}]+\pi\left[\mathrm{dfp}_{(\mathrm{dfppy})}\right]$; LUMO, $\pi^{*}\left[\mathrm{py}_{(\mathrm{dfppy})}\right] .1 \mathrm{~b}:$ HOMO, $\mathrm{d}_{\pi}[\mathrm{Ir}]+$ $\pi\left[\mathrm{dfp}_{(\mathrm{dfpbpy})}\right] ;$ LUMO, $\pi^{*}\left[\mathrm{py}_{(\mathrm{dfpbpy})}\right] \cdot 2:$ HOMO, $\mathrm{d}_{\pi}[\mathrm{Ir}]+\pi\left[\mathrm{dfp}_{(\mathrm{dfpbpy})}\right]$; LUMO, $\pi^{*}\left[\mathrm{py}_{(\mathrm{dfpbpy})}\right]+\pi^{*}\left[\mathrm{py}_{(\mathrm{fppz})}\right] .3: \mathrm{HOMO}-2, \mathrm{~d}_{\pi}[\mathrm{Ir}]+\pi\left[\mathrm{pz}_{(\mathrm{fppz})}\right]$; HOMO, $\mathrm{d}_{\pi}[\mathrm{Ir}]+\pi\left[\mathrm{pz}_{\left(\mathrm{P}^{\wedge} \mathrm{N}\right)}\right] ;$ LUMO, $\pi^{*}[\mathrm{fppz}]$.

butions of the $T_{1}$ state for all of these complexes were calculated to be relatively small, especially for that of 3 $\left(<10 \%\right.$ for $\mathrm{T}_{1}$; see Table 2$)$. These results are well correlated with the experimental observation, in which well-resolved vibronic progression and relatively long radiative lifetimes were recorded for the emission spectra of all four complexes (see Figure 3 and Table 1).

Note that the above assignment is based on the FranckCondon excitation of the geometry-optimized singlet ground state. To further explore the origin of the transition of phosphorescence, Figures 4 and 5 also reveal the spindensity surface for the geometry-optimized triplet excited state of all Ir III metal complexes. The spin-density contours, in theory, reflect regions of excess $\alpha$ and $\beta$ electronic spin. As a result, this diagram implicates that the spin densities involved in the lowest-lying triplet state of 3 are primarily distributed within the fppz ligand, while the spin-density surfaces of $\mathbf{1 a}, \mathbf{1 b}$, and $\mathbf{2}$ are mainly localized at the cyclometalated dfppy ligands. This discrepancy explains the observed difference of transition energy gaps between 3 and the other studied complexes. Because the spin density on the rest of the chelating ligands is not noticeable, the result supports the strategic design of phosphorescence originating from the designated ligating chromophore and central I $^{\text {III }}$ metal atom

Device Fabrication. To obtain a high-efficiency blue/ deep-blue OLED, the balance of carriers and the confinement of excitons play important roles. Host materials of high triplet energies are also indispensable to avoid back energy transfer; hence, the OLED structure containing double- 

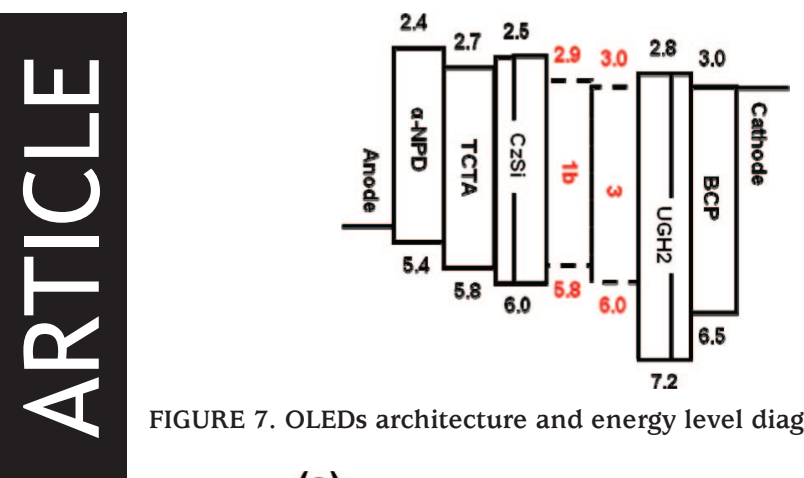

FIGURE 7. OLEDs architecture and energy level diagram.

(a)
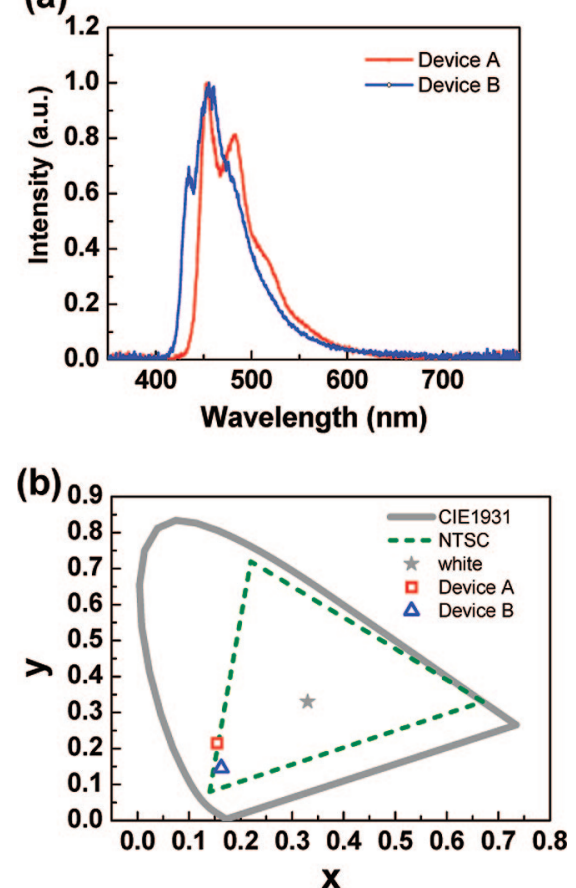

FIGURE 8. (a) EL spectra and (b) CIE chromaticity coordinates for devices $A$ and $B$.

emitting layers, together with double confinement layers, was adopted to achieve a good carrier balance and exciton confinement. Such a configuration also offers the advantage of keeping the exciton formation zone away from the interfaces of adjacent carrier-transport layers (27). Two sets of devices have been optimized to study the effects of dopants $\mathbf{1 b}$ and $\mathbf{3}$; their graphical configuration and materials incorporated are depicted in Figure 7 . Device $A$ is composed of ITO/ $\alpha$-naphthylphenylbiphenyldiamine $(\alpha$ NPD; $30 \mathrm{~nm}$ ) $/ 4,4^{\prime}, 4^{\prime \prime}$-tris(N-carbazolyl)triphenylamine (TCTA; $20 \mathrm{~nm}) / \mathrm{CzSi}(3 \mathrm{~nm}) / \mathrm{CzSi}$ doped with 8 wt \% of $\mathbf{1 b}(35 \mathrm{~nm}) /$ UGH2 doped with 8 wt $\%$ of $\mathbf{1 b}(3 \mathrm{~nm}) / \mathrm{UGH} 2(2 \mathrm{~nm}) / 2,9$ dimethyl-4,7-diphenyl-1,10-phenanthroline (BCP; $50 \mathrm{~nm}$ )/ $\mathrm{Cs}_{2} \mathrm{CO}_{3}(2 \mathrm{~nm}) / \mathrm{Ag}(150 \mathrm{~nm})$. Device $\mathrm{B}$ is fabricated by switching the dopant to $6 \mathrm{wt} \%$ of 3 . The double-emitting layers consist of hole-transporting 9-(4-tert-butylphenyl)-3,6bis(triphenylsilyl)-9H-carbazole (CzSi, $35 \mathrm{~nm}$ ) and electrontransporting $p$-bis(triphenylsilyl)benzene (UGH2, $3 \mathrm{~nm}$ ); both possess relatively large triplet energy gaps of 3.02 and 3.18 $\mathrm{eV}$, respectively $(28,29)$. Accordingly, the triplet excitons are expected to be more effectively confirmed, such that a better carrier balance could be maintained. Moreover, thin and
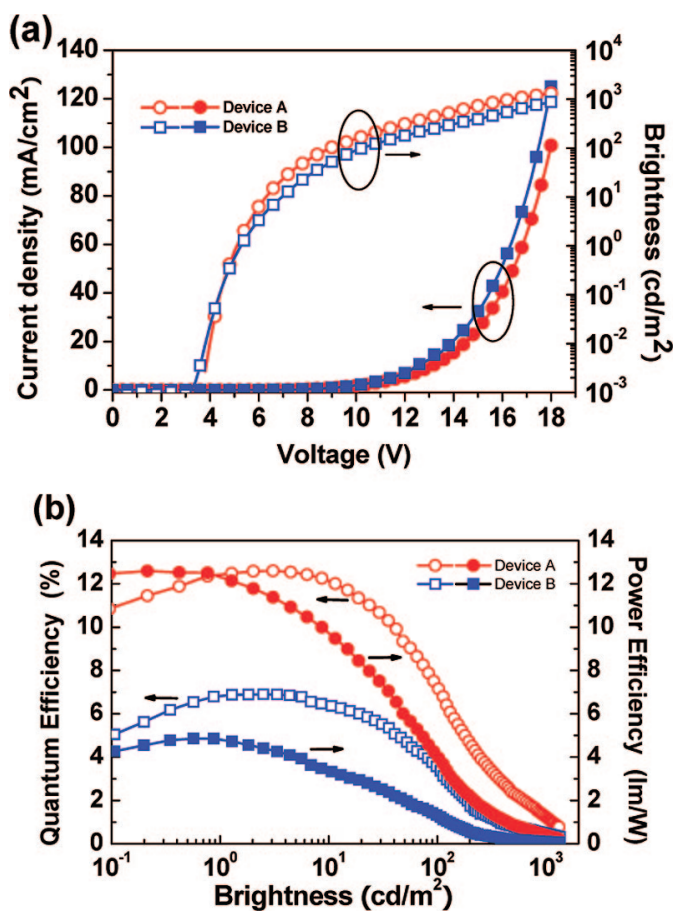

FIGURE 9. (a) $I-V-L$ characteristics and (b) external quantum efficiency and power efficiency versus brightness for devices $A$ and B (circles for device A and squares for device B).

Table 3. Performance Data of a Device Fabricated Employing $1 \mathrm{~b}$ and 3 as Dopants

\begin{tabular}{|c|c|c|c|c|c|}
\hline & & EQE (\%) & $\operatorname{LE}\left(\mathrm{cd} \mathrm{A}^{-1}\right)$ & $\mathrm{PE}\left(\operatorname{lm~W^{-1})}\right.$ & $\begin{array}{c}\mathrm{CIE}_{x, y} \\
\text { (at } 100 \mathrm{~cd} \mathrm{\textrm {m } ^ { - 2 }} \text { ) }\end{array}$ \\
\hline \multirow[t]{2}{*}{$1 b$} & peak & 12.6 & 20.3 & 12.6 & $(0.154,0.215)$ \\
\hline & $100 \mathrm{~cd} \mathrm{~m}^{-2}$ & 7.2 & 11.4 & 4.0 & \\
\hline \multirow[t]{2}{*}{3} & peak & 6.9 & 8.1 & 4.9 & $(0.163,0.145)$ \\
\hline & $100 \mathrm{~cd} \mathrm{~m}^{-2}$ & 3.6 & 4.3 & 1.3 & \\
\hline
\end{tabular}

nondoped CzSi and UGH2 (vide supra) are added between the hole-transport layer (HTL)/electron-transport layer (ETL) and emitting layers for further removal of the emission zone away from the corresponding interfaces, resulting in a better device performance. $\alpha$-NPD and TCTA were used as the HTLs with the aim achieving a better match among their HOMO levels, while BCP was used as the ETL. Finally, to complete the device fabrication, a $2 \mathrm{~nm}$ layer of $\mathrm{Cs}_{2} \mathrm{CO}_{3}$ was used as the electron injection layer (30), while Ag metal was deposited sequentially as the cathode.

As a result, both devices exhibit relatively low turn-on voltages of 3.6 (device A) and 4.0 (device B) V. The EL spectra and the corresponding $\mathrm{CIE}$ chromaticity of these devices are shown in Figure 8. The 1931 Commission Internationale de L'Eclairage coordinates $\left(\mathrm{CIE}_{x, y}\right)$, calculated from their EL spectra, are observed to be $(0.154,0.215)$ and $(0.163,0.145)$ for devices A and B, respectively. Clearly, device B shows a deeper-blue EL versus the colorant that was derived from device A. Figure 9 depicts the $I-V-L$ characteristics and the corresponding EL efficiencies. Of particular interest is that device A shows a peak external quantum efficiency of $12.6 \%$ photon/electron, a peak luminance efficiency of $20.3 \mathrm{~cd} \mathrm{~A}^{-1}$, and a peak power efficiency of $12.6 \mathrm{~lm} \mathrm{~W}^{-1}$, while device $B$ exhibits slightly inferior peak efficiencies of $6.9 \%, 8.1 \mathrm{~cd}$ 
$\mathrm{A}^{-1}$, and $4.9 \mathrm{~lm} \mathrm{~W}^{-1}$ (Table 3). Though device A gives a higher quantum efficiency, device B shows an unusual deeper-blue luminescence, yet both of their efficiencies and color purities are superior to those fabricated from the blue phosphors documented in the literature (31) and, hence, should be well suited for future flat-panel-display or solidstate-lighting applications.

\section{CONCLUSION}

In summary, we report the synthesis and characterization of Ir $^{\text {III }}$ complexes functionalized with substituted pyridyl cyclometalate or azolate chromophores, in combination with a newly designed nonconjugated $\mathrm{P}^{\wedge} \mathrm{N}$ chelate, which, on the one hand, restricts its participation in the electronic transition process and accordingly suppresses, in part, the radiationless pathways associated with its vibronic quenching. On the other hand, its strong ligand field enhances the coordination strength and, hence, diminishes the deactivation processes relevant to shallow potential energy surfaces such as the metal-centered dd transition, for instance. This conceptual design, which is further supported by the corresponding photophysical properties and computational approaches in this study, presents a novel strategy in achieving heretofore uncommon blue to true-blue phosphorescence with high efficiency. Accordingly, fabrication of the device using these blue phosphors as dopants was successfully made. As for the device integration, we emphasize the importance of device configuration, which is composed of multiple emitting and confinement layers, to achieve balance of the carriers and the confinement of excitons simultaneously. Moreover, host materials of high triplet energies also play a prime role in the prohibition of back energy transfer. This is particularly pivotal in achieving high-efficiency OLEDs in the blue/deep-blue region. We thus believe that the design concept of a nonconjugated ancillary $\mathrm{P}^{\wedge} \mathrm{N}$ chelate, its facile synthetic methodology, subtle device integration, and the supportive experimental data presented in this study should convince the readers of its perspective en route to true-blue phosphorescence OLEDs.

Acknowledgment. We are grateful to the National Center for High-Performance Computing for computer time and facilities.

Supporting Information Available: X-ray crystallographic data file (CIF) of complexes $\mathbf{1} \mathbf{b}$ and $\mathbf{3}$ and molecular orbital diagrams of all complexes at their $\mathrm{S}_{0}$-optimized geometry. This material is available free of charge via the Internet at http://pubs.acs.org.

\section{REFERENCES AND NOTES}

(1) (a) Evans, R. C.; Douglas, P.; Winscom, C. J. Coord. Chem. Rev. 2006, 250, 2093. (b) Thompson, M. E. MRS Bull. 2007, 32, 694. (c) So, F.; Krummacher, B.; Mathai, M. K.; Poplavskyy, D.; Choulis, S. A.; Choong, V.-E. J. Appl. Phys. 2007, 102, 091101. (d) Chou, P.-T.; Chi, Y. Chem.-Eur.J. 2007, 13, 380

(2) (a) Tung, Y.-L.; Lee, S.-W.; Chi, Y.; Chen, L.-S.; Shu, C.-F.; Wu F.-I.; Carty, A. J.; Chou, P.-T.; Peng, S.-M.; Lee, G.-H. Adv. Mater. 2005, 17, 1059. (b) Tung, Y.-L.; Chen, L.-S.; Chi, Y.; Chou, P.-T.; Cheng, Y.-M.; Li, E. Y.; Lee, G.-H.; Shu, C.-F.; Wu, F.-I.; Carty, A. J. Adv. Funct. Mater. 2006, 16, 1615.
(3) (a) Chi, Y.; Chou, P.-T. Chem. Soc. Rev. 2007, 36, 1421. (b) Chou, P.-T.; Chi, Y. Eur. J. Inorg. Chem. 2006, 3319.

(4) (a) Holder, E.; Langeveld, B. M. W.; Schubert, U. S. Adv. Mater. 2005, 17, 1109. (b) Flamigni, L.; Barbieri, A.; Sabatini, C.; Ventura, B.; Barigelletti, F. Top. Curr. Chem. 2007, 281, 143. (c) Nazeeruddin, M. K.; Gratzel, M. Struct. Bonding 2007, 123, 113. (c) Burn, P. L.; Lo, S.-C.; Samuel, I. D. W. Adv. Mater. 2007, 19, 1675.

(5) (a) Lai, S.-W.; Che, C.-M. Top. Curr. Chem. 2004, 241, 27. (b) Wong, W.-Y.; He, Z.; So, S.-K.; Tong, K.-L.; Lin, Z. Organometallics 2005, 24, 4079. (c) Chang, S.-Y.; Kavitha, J.; Li, S.-W.; Hsu, C.-S.; Chi, Y.; Yeh, Y.-S.; Chou, P.-T.; Lee, G.-H.; Carty, A. J.; Tao, Y.-T.; Chien, C.-H. Inorg. Chem. 2006, 45, 137. (d) He, Z.; Wong, W.-Y.; Yu, X.; Kwok, H.-S.; Lin, Z. Inorg. Chem. 2006, 45, 10922. (e) Williams, J. A. G.; Wilkinson, A. J.; Whittle, V. L. Dalton Trans. 2008, 2081. (f) Chang, S.-Y.; Cheng, Y.-M.; Chi, Y.; Lin, Y.-C.; Jiang, C.-M.; Lee, G.-H.; Chou, P.-T. Dalton Trans. 2008, 6901

(6) (a) Sun, Y.; Giebink, N. C.; Kanno, H.; Ma, B.; Thompson, M. E.; Forrest, S. R. Nature 2006, 440, 908. (b) D'Andrade, B. Nat. Photonics 2007, 1, 33.

(7) (a) Kawamura, Y.; Goushi, K.; Brooks, J.; Brown, J. J.; Sasabe, H.; Adachi, C. Appl. Phys. Lett. 2005, 86, 071104. (b) Williams, E. L.; Haavisto, K.; Li, J.; Jabbour, G. E. Adv. Mater. 2007, 19, 197. (c) Tong, B.; Mei, Q.; Wang, S.; Fang, Y.; Meng, Y.; Wang, B. J. Mater. Chem. 2008, 18, 1636 .

(8) (a) Wong, W.-Y.; Ho, C.-L.; Gao, Z.-Q.; Mi, B.-X.; Chen, C.-H.; Cheah, K.-W.; Lin, Z. Angew. Chem., Int. Ed. 2006, 45, 7800. (b) Zhou, G.; Wong, W.-Y.; Yao, B.; Xie, Z.; Wang, L. Angew. Chem., Int. Ed. 2007, 46, 1149. (c) Ho, C.-L.; Wong, W.-Y.; Zhou, G.-J.; Yao, B.; Xie, Z.; Wang, L. Adv. Funct. Mater. 2007, 17, 2925. (d) Ho, C.-L.; Wong, W.-Y.; Gao, Z.-Q.; Chen, C.-H.; Cheah, K.-W.; Yao, B.; Xie, Z.; Wang, Q.; Ma, D.; Wang, L.; Yu, X.-M.; Kwok, H.-S.; Lin, Z. Adv. Funct. Mater. 2008, 18, 319. (e) Zhou, G.; Ho, C.-L.; Wong, W.-Y.; Wang, Q.; Ma, D.; Wang, L.; Lin, Z.; Marder, T. B.; Beeby, A. Adv. Funct. Mater. 2008, 18, 499. (f) Ho, C.-L.; Wong, W.-Y.; Wang, Q.; Ma, D.; Wang, L.; Lin, Z. Adv. Funct. Mater. 2008, 18, 928. (g) Chien, C.-H.; Liao, S.-F.; Wu, C.-H.; Shu, C.-F.; Chang, S.-Y.; Chi, Y.; Chou, P.-T.; Lai, C.-H. Adv. Funct. Mater. 2008, 18, 1430. (h) Zhou, G.; Wang, Q.; Ho, C.-L.; Wong, W.-Y.; Ma, D.; Wang, L.; Lin, Z. Chem. Asian J. 2008, 3, 1830.

(9) (a) Li, J.; Djurovich, P. I.; Alleyne, B. D.; Yousufuddin, M.; Ho, N. N.; Thomas, J. C.; Peters, J. C.; Bau, R.; Thompson, M. E. Inorg. Chem. 2005, 44, 1713. (b) Lo, S.-C.; Richards, G. J.; Markham, J. P. J.; Namdas, E. B.; Sharma, S.; Burn, P. L.; Samuel, I. D. W. Adv. Funct. Mater. 2005, 15, 1451. (c) Avilov, I.; Minoofar, P.; Cornil, J.; De Cola, L. J. Am. Chem. Soc. 2007, 129, 8247. (d) Su, S.-J.; Sasabe, H.; Takeda, T.; Kido, J. Chem. Mater. 2008, 20, 1691. (e) Orselli, E.; Albuquerque, R. Q.; Fransen, P. M.; Froehlich, R.; Janssen, H. M.; De Cola, L. J. Mater. Chem. 2008, 18, 4579.

(10) (a) Holmes, R. J.; D’Andrade, B. W.; Forrest, S. R.; Ren, X.; Li, J.; Thompson, M. E. Appl. Phys. Lett. 2003, 83, 3818. (b) Zheng, Y.; Eom, S.-H.; Chopra, N.; Lee, J.; So, F.; Xue, J. Appl. Phys. Lett. 2008, 92, 223301

(11) (a) Wu, P.-C.; Yu, J.-K.; Song, Y.-H.; Chi, Y.; Chou, P.-T.; Peng, S.-M.; Lee, G.-H. Organometallics 2003, 22, 4938. (b) Yu, J.-K.; Hu, Y.-H.; Cheng, Y.-M.; Chou, P.-T.; Peng, S.-M.; Lee, G.-H.; Carty, A. J.; Tung, Y.-L.; Lee, S.-W.; Chi, Y.; Liu, C.-S. Chem--Eur.J. 2004, 10,6255

(12) Cheng, Y.-M.; Li, E. Y.; Lee, G.-H.; Chou, P.-T.; Lin, S.-Y.; Shu, C.F.; Hwang, K.-C.; Chen, Y.-L.; Song, Y.-H.; Chi, Y. Inorg. Chem. 2007, 46, 10276

(13) Yeh, Y.-S.; Cheng, Y.-M.; Chou, P.-T.; Lee, G.-H.; Yang, C.-H.; Chi, Y.; Shu, C.-F.; Wang, C.-H. ChemPhysChem 2006, 7, 2294.

(14) Chang, C.-J.; Yang, C.-H.; Chen, K.; Chi, Y.; Shu, C.-F.; Ho, M.-L.; Yeh, Y.-S.; Chou, P.-T. Dalton Trans. 2007, 1881

(15) Song, Y.-H.; Chiu, Y.-C.; Chi, Y.; Cheng, Y.-M.; Lai, C.-H.; Chou, P.-T.; Wong, K.-T.; Tsai, M.-H.; Wu, C.-C. Chem.-Eur.J. 2008, 14, 5423.

(16) (a) Chang, C.-F.; Cheng, Y.-M.; Chi, Y.; Chiu, Y.-C.; Lin, C.-C.; Lee, G.-H.; Chou, P.-T.; Chen, C.-C.; Chang, C.-H.; Wu, C.-C. Angew. Chem., Int. Ed. 2008, 47, 4542. (b) Chiu, Y.-C.; Hung, J.-Y.; Chi, Y.; Chen, C.-C.; Chang, C.-H.; Wu, C.-C.; Cheng, Y.M.; Yu, Y.-C.; Lee, G.-H.; Chou, P.-T. Adv. Mater. 2009, DOI: adma.200802546.

(17) (a) Perdew, J. P.; Burke, K.; Ernzerhof, M. Phys. Rev. Lett. 1996, 77, 3865. (b) Perdew, J. P.; Burke, K.; Ernzerhof, M. Phys. Rev. Lett. 1997, 78, 1396. (c) Adamo, C.; Barone, V. J. Chem. Phys. $1999,110,6158$ 
(18) (a) Hay, P. J.; Wadt, W. R. J. Chem. Phys. 1985, 82, 270. (b) Wadt, W. R.; Hay, P. J.J. Chem. Phys. 1985, 82, 284. (c) Hay, P. J.; Wadt, W. R. J. Chem. Phys. 1985, 82, 299.

(19) (a) Jamorski, C.; Casida, M. E.; Salahub, D. R. J. Chem. Phys. 1996 104, 5134. (b) Petersilka, M.; Grossmann, U. J.; Gross, E. K. U. Phys. Rev. Lett. 1996, 76, 1212. (c) Bauernschmitt, R.; Ahlrichs, R.; Hennrich, F. H.; Kappes, M. M. J. Am. Chem. Soc. 1998, 120, 505. (d) Casida, M. E. J. Chem. Phys. 1998, 108, 4439. (e) Stratmann, R. E.; Scuseria, G. E.; Frisch, M. J.J. Chem. Phys. 1998, 109, 8218.

(20) Gaussian 03, revision C.02; Gaussian, Inc.: Wallingford, CT, 2004

(21) Eum, M.-S.; Chin, C. S.; Kim, S. y.; Kim, C.; Kang, S. K.; Hur, N. H Seo, J. H.; Kim, G. Y.; Kim, Y. K. Inorg. Chem. 2008, 47, 6289

(22) (a) Yang, C.-H.; Li, S.-W.; Chi, Y.; Cheng, Y.-M.; Yeh, Y.-S.; Chou, P.-T.; Lee, G.-H.; Wang, C.-H.; Shu, C.-F. Inorg. Chem. 2005, 44, 7770. (b) Song, Y.-H.; Yeh, S.-J.; Chen, C.-T.; Chi, Y.; Liu, C.-S.; Yu, J.-K.; Hu, Y.-H.; Chou, P.-T.; Peng, S.-M.; Lee, G.-H. Adv. Funct. Mater. 2004, 14, 1221

(23) (a) Chen, L.; You, H.; Yang, C.; Ma, D.; Qin, J. Chem. Commun. 2007, 1352. (b) You, Y.; Seo, J.; Kim, S. H.; Kim, K. S.; Ahn, T. K. Kim, D.; Park, S. Y. Inorg. Chem. 2008, 47, 1476. (c) Byun, Y.; Jeon, W. S.; Lee, T.-W.; Lyu, Y.-Y.; Chang, S.; Kwon, O.; Han, E.; Kim, H.; Kim, M.; Lee, H.-J.; Das, R. R. Dalton Trans. 2008, 4732.

(24) (a) Mak, C. S. K.; Hayer, A.; Pascu, S. I.; Watkins, S. E.; Holmes, A. B.; Koehler, A.; Friend, R. H. Chem. Commun. 2005, 4708. (b) Wu, L.-L.; Yang, C.-H.; Sun, I.-W.; Chu, S.-Y.; Kao, P.-C.; Huang, H.-H. Organometallics 2007, 26, 2017. (c) Orselli, E.; Kottas, G. S.; Konradsson, A. E.; Coppo, P.; Froehlich, R.; De Cola, L.; van Dijken, A.; Buechel, M.; Boerner, H. Inorg. Chem. 2007, 46, 11082 .

(25) Laskar, I. R.; Hsu, S.-F.; Chen, T.-M. Polyhedron 2005, 24, 189
(26) (a) De Angelis, F.; Fantacci, S.; Evans, N.; Klein, C.; Zakeeruddin, S. M.; Moser, J.-E.; Kalyanasundaram, K.; Bolink, H. J.; Graetzel, M.; Nazeeruddin, M. K. Inorg. Chem. 2007, 46, 5989. (b) He, L.; Duan, L.; Qiao, J.; Wang, R.; Wei, P.; Wang, L.; Qiu, Y. Adv. Funct. Mater. 2008, 18, 2123. (c) Di Censo, D.; Fantacci, S.; De Angelis, F.; Klein, C.; Evans, N.; Kalyanasundaram, K.; Bolink, H. J.; Graetzel, M.; Nazeeruddin, M. K. Inorg. Chem. 2008, 47, 980.

(27) (a) Zhou, X.; Qin, D. S.; Pfeiffer, M.; Blochwitz-Nimoth, J.; Werner, A. D. J.; Maennig, B.; Leo, K.; Bold, M.; Erk, P.; Hartmann, H. Appl. Phys. Lett. 2002, 81, 4070. (b) He, G.; Pfeiffer, M.; Leo, K.; Hofmann, M.; Birnstock, J.; Pudzich, R.; Salbeck, J. Appl. Phys. Lett. 2004, 85, 3911

(28) Tsai, M.-H.; Lin, H.-W.; Su, H.-C.; Ke, T.-H.; Wu, C.-C.; Fang, F.C.; Liao, Y.-L.; Wong, K.-T.; Wu, C.-I. Adv. Mater. 2006, 18, 1216.

(29) Ren, X.; Li, J.; Holmes, R. J.; Djurovich, P. I.; Forrest, S. R.; Thompson, M. E. Chem. Mater. 2004, 16, 4743.

(30) Wu, C. I.; Lin, C. T.; Chen, Y. H.; Chen, M. H.; Lu, Y. J.; Wu, C. C. Appl. Phys. Lett. 2006, 88, 152104.

(31) (a) Yeh, S.-J.; Wu, M.-F.; Chen, C.-T.; Song, Y.-H.; Chi, Y.; Ho, M.H.; Hsu, S.-F.; Chen, C. H. Adv. Mater. 2005, 17, 285. (b) Wu, M.F.; Yeh, S.-J.; Chen, C.-T.; Murayama, H.; Tsuboi, T.; Li, W.-S.; Chao, I.; Liu, S.-W.; Wang, J.-K. Adv. Funct. Mater. 2007, 17, 1887. (c) Shih, P.-I.; Chien, C.-H.; Chuang, C.-Y.; Shu, C.-F.; Yang, C.H.; Chen, J.-H.; Chi, Y.J. Mater. Chem. 2007, 17, 1692. (d) Wang, Y.-M.; Teng, F.; Gan, L.-H.; Liu, H.-M.; Zhang, X.-H.; Fu, W.-F.; Wang, Y.-S.; Xu, X.-R. J. Phys. Chem. C 2008, 112, 4743. (e) Yang, L.; Okuda, F.; Kobayashi, K.; Nozaki, K.; Tanabe, Y.; Ishii, Y.; Haga, M. Inorg. Chem. 2008, 47, 7154

AM800122N 